\title{
WestVirginiaUniversity.
}

Department of Economics

Working Paper Series

\section{The Impact of Microfinance on Pro- Social Behaviors: Experimental Evidence of Public Goods Contributions in Uganda}

Bryan C. McCannon

Zachary Rodriguez

Working Paper No. 16-13

This paper can be found at the College of Business and Economics Working Paper Series homepage: 


\title{
The Impact of Microfinance on Pro-Social Behaviors: Experimental Evidence of Public Goods Contributions in Uganda
}

\author{
Bryan C. McCannon ${ }^{+}$ \\ West Virginia University \\ Zachary Rodriguez ${ }^{++}$ \\ Saint Bonaventure University
}

24 February $2016^{*}$

\begin{abstract}
We ask whether access to microfinance loans by the poor has a spillover effect on their pro-social behaviors. An experimental field study in southern, rural Uganda is conducted using free riding in public goods contributions as an assessment. We document higher levels of contributions by those who have previously received a microloan. This effect cannot be explained by changes in social norms, income effects, or sample selection bias. The results suggest that exposure to microfinance promotes social preferences.
\end{abstract}

Keywords: experiment, field study, free riding, microfinance, public goods, social norm, social preference, Uganda

\footnotetext{
+ Corresponding author: Department of Economics, School of Business and Economics, West Virginia University, P.O. Box 6025, Morgantown, WV 26506, bryan.c.mccannon@gmail.com.

${ }^{++}$School of Business, Saint Bonaventure University, 3261 W. State Road, Saint Bonaventure, NY 14778, rachzt14@bonaventure.edu

* We are greatly indebted to the numerous local-community volunteers who aided in the field. We are particularly indebted to Kuteesa Elijah, Kayima Jackson, Namugera Ronald, and Mugisha Linous Fredrick for help in recruiting, managing the two-day field study, and working as translators. We would also like to thank Kim McCannon for being a lovely research assistant and, importantly, the director of Bethlehem Parent's School, Sserwangu Fredrick, for his hospitality, efforts prior to and during the field study, and translating services. We would also like to thank Greg DeAngelo, Craig Mclntosh, Andrew Pohlman, Mark Wilson, Bruce Wydick, and Andy Young for their helpful discussions regarding the design, implementation, and analysis of the project.
} 


\section{Introduction}

Microfinance provides small loans to entrepreneurs in, predominantly, less-developed countries. It is generally viewed as a cornerstone in the fight against poverty and, consequently, numerous non-profit efforts have implemented microfinance programs. Proponents of microfinance argue that it provides credit in areas without other financial institutions. Moral hazard and adverse selection, combined with small transaction amounts, limit the possibilities for traditional banks to lend profitably (Stiglitz, 1990; Ghatak, 1999; 2000; Ghatak and Guinnane, 1999). Microcredit charges lower interest rates, which allows for the capital accumulation needed to be self-sufficient (Banerjee and Duflo, 2011). Mechanisms such as group lending reduces moral hazard problems and peer selection mitigates adverse selection and, consequently, reduces monitoring costs (Rai and Sjöström, 2004; Bond and Krishnamurthy, 2004).

A lively academic debate exists evaluating the effectiveness of microfinance since the successes of the early efforts of the Grameen Bank in Bangladesh (Pitt and Khandker, 1998; Yunus, 1999). There are those that are of the opinion that microfinance is a necessary tool to leading people out of poverty (Sachs, 2008): Alternatively, numerous empirical studies find either negligible impacts, or that its benefits do not persist over time (Banerjee, Karlan, and Zinman, 2015). This leads skeptics to claim that the promises of microfinance are often overstated and unsubstantiated (Murdoch, 1999a; 1999b). Relatedly, Karlan et al. (2014) present evidence from farmers in Ghana that uninsured risk may be more important than credit market constraints. Concern that financial institutions may disrupt relatively effective informal mechanism, such as community or family-based lending, have been expressed (Conning and Udry, 2005). Additionally, El-Gamal et al. (2014) point out its ineffectiveness in Muslim countries due to its rejection based on religious grounds.

Therefore, given the prevalence of microfinance in economic development efforts and the current debates regarding its appropriateness, it is prudent to measure its impact. There is one consequence, though, that has not received attention. Empirical studies evaluating microfinance focus on the measurable economic impacts such as income, consumption, employment, hours worked, and health outcomes. We propose that microfinance spills over onto pro-social behaviors towards others in the communities. In any group, individuals differ in their willingness to free ride off of others, trust and reciprocate, and engage in activities that have positive or negative externalities, to name a few. The focus here is on the willingness to contribute to a public good. In an environment with missing or ineffectual publicly-provided services, private public good contributions are essential (Kremer and 
Miguel, 2007). With them, individuals are faced with private losses trading off with non-excludable gains of others. While a selfish person can be expected to free ride and not contribute, an individual can, alternatively, choose to engage in pro-social behaviors and donate. We ask whether exposure to microfinance changes individual's other-regarding behaviors.

There is reason to believe this is the case. Microfinance can move individuals from subsistence agriculture to market trading. Market experience has been shown to reduce the prevalence of irrational behavior, such as hypothetical bias (List, 2001), endowment effect bias (List, 2003) and GARP violations (List and Millimet, 2008). ${ }^{1}$ Research in financial markets suggests that less-experienced investors, relative to more-experienced market participants, succumb to behavioral limitations such as representation bias (Chen et al., 2007), overconfidence (Odean, 1999), and disposition effect (Odean, 1998a; 1998b). The relationship between experience and loss aversion (Haigh and List, 2005; Pope and Schweitzer, 2011) and ability to play minmax strategies have also been investigated (Palacios-Huerta and Volij, 2008; Levitt, List, and Reilly, 2010). Gode and Sunder (1993) present evidence that markets discipline individuals' behavior even with zero-intelligence participants. Results presented by Farber (2015) suggest that income targeting, that is, labor supply decisions based on achieving a referencepoint level of income, becomes less prevalent with market experience. Bowles (1998) provides a thorough review of mechanisms through which markets and other economic institutions may directly alter preferences. He argues, to provide two examples, that market interactions reinforce extrinsic motivations and that exposure to new tasks adjusts values. Thus, market interactions have the potential to affect individuals' preferences and behaviors. Along with market interactions, there is evidence that the close interaction between microfinance recipients builds social capital that leads to more future contact amongst the receivers, willingness to share risk, and ultimately improved repayment rates (Feigenberg, Field, and Pande, 2013; Feigenberg et al., 2014). Furthermore, negative events, such as community breakups (Barr, 2003), natural disasters (Whitt and Wilson, 2007), and civil war (Cassar, Grosjean, and Whitt, 2013; Becchetti, Conzo, and Romeo, 2014) have shown to diminish pro-social behaviors. Thus, the positive-welfare interactions facilitated by microfinance can be expected to improve these preferences. Similarly, exposure to differing socio-political institutions can alter preferences. As a prominent example, Ariely et al. (2015) document in a field study experiment lower levels of honesty of individuals with an East German family background, as compared to those with a

\footnotetext{
${ }^{1}$ Hypothetical bias is the mis-assessment of hypothetical valuations, relative to real valuation questions. Representation bias is believing that past outcomes are indicative of future outcomes. Disposition effect is the tendency to sell gains and hold losses.
} 
West German family background. Alesina and Fuchs-Schündeln (2007) present evidence of a persistent gap between former West and East Germans on preferences for state intervention. Thus, exposure to new social institutions can be expected to alter preferences.

Thus, to address this question, we conduct a field study experiment in rural, southern Uganda where poverty is prevalent and microfinance has been active. Subjects engaged in a common, simple public goods game and information is collected regarding their exposure to microfinance in the past. We first document that there is a large and strong positive relationship. Individuals who have previously received microfinance loans contribute more to the public good in our experiment. Their contribution is approximately $10 \%$ higher. We then explore the channels through which microfinance can lead to prosocial behaviors. Evidence is provided that it is not due to income effects, improved social norms, or sample selection bias. Rather, exposure to microfinance encourages and influences social preferences.

Our results contribute to two important literatures. The first is the study of the impact of microfinance. Numerous studies have attempted to measure the impacts of microfinance loans on the recipients. Access to microfinance has been shown to improve profits and incomes (Banerjee, Duflo, Glennester, and Kinnan, 2015), employment (Augsburg et al., 2015), investment (Crépon, Devoto, Duflo, and Parienté, 2015), return on capital (de Mel, McKenzie, and Woodruff, 2008), food consumption (Pitt and Khandkar, 1998; Attanasio et al., 2015), health outcomes (Hamad, Fernald, and Karlan, 2011), and subjective well-being (Karlan and Zinman, 2011). See Kaboski and Townsend (2011; 2012) for its wideranging benefits. Karlan (2007) provides evidence the peer monitoring is effective at encouraging repayment. A number of studies, though, find only limited or negligible impacts. Banerjee et al. (2015) find evidence that the initial improvements do not persist after two years. Similar findings (or rather, lack of findings) arise in Angelucci, Karlan, and Zinman (2015) and Tarozzi, Desai, and Johnson (2015), while previous, supportive empirical findings may not be robust (Roodman and Morduch, 2014). The particular strategies employed have received significant attention as well. For example, Karlan and Valdivia (2011) consider the inclusion of business training in microfinance loans in Peru. The effect of repayment frequency is studied by Field and Pande (2008), consequence of the regularity of group meetings is analyzed by Feigenberg, Field, and Pande (2013) and Feigenberg et al. (2014), impact of grace periods is considered by Field et al. (2013), and use of dynamic incentives (i.e., access to future loans) is considered by Tedeschi (2006). The effect of microfinance competition is investigated by McIntosh and Wydick (2005) and McIntosh, de Janvry, and Sadoulet (2005). Also, bundling microcredit with mandated health insurance discourages microfinance demand (Banerjee, Duflo, Hornbeck, 2014). The impact of regulation on microfinance efforts is investigated by Cull, Demirgüç-Kunt, and Morduch 
(2011), while Cull, Demirgüç-Kunt, and Morduch (2007; 2009) study the tension between microfinance lender's ability to improve the welfare of the people they serve and their own profitability. The use of text message reminders of an upcoming payment due by microloan recipients in the Philippines is investigated by Karlan, Morten, and Zinman (2016) and the administration of self-help, group savings is studied by Greaney, Kaboski, and Van Lemmput (2016). Thus, we contribute to this extensive literature by bringing to light the spillover onto social preferences.

The closest work related to ours is Karlan (2005). He conducted experiments of the Trust Game, commonly used to measure the pro-social behaviors of trust and reciprocity, in Peru with recipients of microfinance loans. The primary finding is that behavior in the game is a good predictor of later defaults on the microloans. His work supports our contention that the laboratory experiments can be taken to the field and used as an assessment tool to measure differences between subjects to, specifically, evaluate microfinance. The important distinction, other than considering a different pro-social behavior (trustworthiness), is that he restricts attention to the pool of individuals who have received the microloans, whereas we consider everyone in the community to directly study the impact of microfinance. ${ }^{2}$ Casssar, Crowley, and Wydick (2007) conducts a similar study playing the Trust Game and a microfinance game with microloan recipients in South Africa and Armenia, correlating behavior with repayment.

Also, closely related to our work is that of Giné et al. (2010). They conduct laboratory experiments in Peru. The games they implement are microfinance games with treatments differing in important dimensions of real-world microfinance, such as joint-liability, peer selection, communication, and monitoring. Varying these dimensions, decisions to select safe versus risky investments are made. Their experimental subjects were small-scale entrepreneurs in Lima, who are argued to be similar in demographic characteristics to microfinance participants. Again, in comparison to the work presented here, their work shares the desire to take decision problems to the field and involve as subjects individuals who are directly targeted by the economic intervention. In contrast, their subject pool does not have both recipients and non-recipients of microloans, as they do not attempt to study the impact of microfinance on behaviors. Similarly, Bauer, Chytilová, and Morduch (2012) conduct experimental assessments of time preferences and risk preferences in India. They find that present-biased women are more likely to borrow from a microfinance organization. Finally, Feigenberg, Field, and Pande (2013)

\footnotetext{
${ }^{2}$ Karlan (2005) also plays a version of the Public Goods Game but does not find statistically significant results with repayments. Relevant to our study, though, is that his sample is recipients of microloans from FINCA, who is also an organization operating in Uganda and one that some subjects in our pool had experience with.
} 
include an experimental risk-sharing game to assess the impact of the frequency of group meetings of microloan recipients, while Fischer (2013) investigates the relationship between contract structure and risk sharing.

The other literature we contribute to is the experimental investigation of public goods contributions. Work studying public goods giving in the laboratory can be categorized into two broad approaches. The first is to free riding in differing institutional environments. Prominent examples include the study of communication (Oprea, Charness, and Friedman, 2014), punishments (Fehr and Gächter, 2000), expulsion (Cinyabuguma, Page, and Putterman, 2005), group size (Isaac and Walker, 1988), and asymmetric endowments (Buckley and Croson, 2006) to name a few. The second category, to which we directly contribute, is to use the donation decisions as an assessment tool to differentiate amongst individuals with heterogeneous preferences. This literature, then, searches for correlates to the contributions to appreciate the factors that influence one's social preferences. Examples include identifying the impact of gender (Nowell and Tinkler, 1994), hurricanes (Whitt and Wilson, 2007), religion (Anderson and Mellor, 2009), finance education (McCannon, 2014), corruption (Beekman, Bulte, and Nilleson, 2015), and leadership (Jack and Recalde, 2015).

We are not the first to conduct economic experiments in the field in Africa. ${ }^{3}$ Barr (2003) for example, plays the Trust Game in rural villages in Zimbabwe. She compares behavior of individuals in those villages that have stayed in-tact for generations to individuals in villages who have been reconstituted after the land re-allocation policies in the country. Cassar and Wydick (2010) conduct a group lending experiment with subjects in five countries, including Kenya. Studying motivations to enter the non-profit health services, Sera, Serneels, and Barr (2011) survey individuals in Ethiopia. Becchetti, Conzo, and Romeo (2014) also conduct experiments of the Trust Game, but do so in the slums of Nairobi, Kenya. They document the effect of exposure to violence from a civil war. Lehrer and Porter (2015) conduct a field study experiment in Kampala, Uganda playing the Dictator Game where subjects can contribute money to a charity. Fafchamps and Hill (2015) consider giving, stealing, and burning of money by others in a group when subjects can voluntarily join using subjects from Uganda, Kenya, and the UK. Beekman, Bulte, and Nilleson (2015) investigate the impact of corruption on public goods giving in Liberia. Bryan, Karlan, and Zinman (2015) conduct a field study experiment with microfinance recipients in South Africa. To appreciate peer selection versus peer monitoring effects they compare behaviors amongst individuals who are compensated for referring potential borrowers to a microfinance

\footnotetext{
${ }^{3}$ For a collection of field study experiments in non-Western cultures see Henrich et al. (2004) with a summary investigation in Henrich et al. (2001).
} 
organization. Jakiela and Owen (2016) conduct a field study in Kenya where social pressures to share income are prevalent and show that women will act to conceal their wealth even when it leads to lower expected returns.

In Section 2 of the paper, the microfinance efforts in rural, southern Uganda, the sight of the field study, are outlined. Section 3 presents the competing hypotheses of how microfinance may influence pro-social behaviors. Section 4 presents the experimental methods employed. The setting, game, subjects, and procedures are elaborated upon. Section 5 presents descriptive findings establishing a connection between microfinance exposure and free riding, while Section 6 conducts the formal econometric investigation. Section 7 concludes.

\section{Microfinance in Southern, Rural Uganda}

Uganda is a country in economic distress. GDP per capita is only $\$ 1900$, which puts it at \#202 in the world. Eight-two percent of the labor force is engage in agriculture. Its citizens also suffer from poor health. Life expectancy is less than age 55 , which puts it \#211 in the world. The median age of the population is 15.6 years old. Overall, $7.25 \%$ of the population is living with HIV/AIDS with approximately 33,000 AIDS-related deaths per year, putting it well within the top ten in the world. ${ }^{4}$

The Rakai District of southern Uganda has received quite a bit of attention as the epicenter for the AIDS epidemic. For example, in the 1990s it is estimated that $16.1 \%$ of the population above the age of fourteen had HIV, leading to a death rate of 209.4 per 1000 amongst infants born by HIV-infected mothers (Sewankambo et al., 2000). In fact, the Rakai district is the place of the first recorded case of HIV/AIDS in the country and is, therefore, referred to as the birthplace of AIDS in Uganda (Mutyaba, 2014). It is estimated that $31.3 \%$ of households in Rakai have at least one HIV-infected individual (Nalugoda et al., 1997). In fact, Johns Hopkins University AIDS research center is located in Rakai. The crisis leaves in its aftermath many widows and orphans. HIV/AIDS is not the only disease of concern. Over $50 \%$ of poor-health cases are those with malaria, for example. ${ }^{5}$ The human crisis has lead philanthropists to focus attention on the district. Much of these efforts have included development through microfinance.

\footnotetext{
${ }^{4}$ https://www.cia.gov/library/publications/resources/the-world-factbook/geos/ug.html

${ }^{5}$ Information on Johns Hopkins' activities can be found at http://www.jhsph.edu/research/centers-andinstitutes/rakai-health-sciences-program/about/. Evidence of other health issues is available at http://www.ubos.org/onlinefiles/uploads/ubos/2009_HLG_\%20Abstract_printed/ Rakai\%20district\%20statistical\%20abstract.pdf.
} 
The microfinance industry has been present in Uganda since the mid-1980s (Carlton et al., 2001). Many early microfinance efforts, like Women's Finance and Credit Trust and Orphans Community Based Organisation, were established as social welfare programs, particularly in response to the HIV/AIDS pandemic. These initiatives would be referred to as Savings and Credit Cooperatives (SACCOs), rather than microfinance institutions (MFIs). It was in the early 1990s that more formal MFIs began operating in Uganda. There has been a substantial amount of interest in developing microenterprises in the country (Blattman, Fiala, and Martinez, 2014).

It is important to make a distinction between a savings and credit cooperative and microfinance institutions. A SACCO is a not-for-profit, member-owned organization. Members traditionally share a common relationship, like being in a similar vocation or living in the same community. In contrast, a MFI is a credit institution funded by external loans, grants, or investors. Appointed boards of directors that may not have a physical presence in the country traditionally run the MFIs.

Throughout the Rakai district, there are approximately fifty registered SACCOs, but it is unclear how many of these organizations are actually in operation. ${ }^{6}$ There are also several MFIs operating in the district. Two prominent organizations active in the area are FINCA International and BRAC International. Though each SACCO and MFI has their own eligibility standards, in general, microfinance targets lowincome clients, particularly women, for either savings or credit products. In terms of credit, each organization offers microloans both to groups and individuals, but there is an emphasis on the group loan model. ${ }^{7}$ BRAC began operations in Uganda in 2006 and has made loans to 166,343 Ugandans. FINCA entered Uganda in 1992 and has, to date, lent to 148,343 people. ${ }^{8}$ Both BRAC and FINCA offer similar financial products to their clients. Each offer individual loans with monthly interest rates between 2.5-3\%. Individual loans can have durations of six months, eight months, one year, or two years. Loan duration is dependent on the client. Both organizations also offer group loans that offer monthly interest rates of 3.5\% and on average consist of five to ten people. Before an individual can receive a loan, one must go through "pre-disbursement training", which explains the terms and conditions of the loan, assesses the client's credit history and ability to manage the loan, and any assets owned by the client.

\footnotetext{
6 “The Microfinance Support Centre Ltd. Outreach Map", http://www.msc.co.ug/index.php/about-us/outreachmap. (January 27, 2016).

${ }^{7}$ Uganda Microfinance Industry Assessment, 2008. http://www.amfiu.org.ug/images/docs/Studies/industryassessment2008.pdf

${ }^{8} \mathrm{~A}$ description of BRAC's activities in Uganda is available at http://uganda.brac.net/images/BRAC_Uganda_factsheet.pdf. Information on FINCA can be found at http://www.finca.org/where-we-work/africa/uganda/
} 
In 2008, Embrace It Africa, Inc. (EIA), a 501c3 non-profit organization, established a savings and credit cooperative under the name, Mikwano Microfinance. "Mikwano" means friendship in the Luganda language, which is the most widely spoken tribal language in Uganda. The regulations and operations of the cooperative were created in close collaboration with community members to ensure that its services and processes make the highest impact on the lives of its clients given their geographic, economic, or social circumstances. ${ }^{9}$

Mikwano Microfinance offers a $2.5-3 \%$ monthly interest rate on its microloans. In its funding model, loan recipients are grouped into cohorts of four or five. The organization also requires loan recipients to contribute some earnings from the loan to an area orphanage. This could be in the form of a capital contribution or in-kind donations, like crop yield or livestock. These eligibility requirements were developed through the research of other microfinance initiatives and, in particular, the work of Muhammad Yunus and the Grameen Bank.

Consequently, Rakai is the ideal location for this study. The high degree of poverty, due in large part to counterproductive governance ${ }^{10}$, limited education, and health crises has encouraged charitable efforts focusing on economic development through microfinance. Additionally, the microfinance interventions have been going on for a number of years and, thus, any impact it has can be expected to have been expressed. Finally, through direct support and participation from Mikwano Microfinance, access to the community is available and facilities are provided.

\section{Theory}

How might microfinance exposure influence free riding behavior? It is well-established that the selfish-man framework of the maximization of utility through consumption, or rather, expected wealth maximization does not fully describe individual-level decisions. Numerous experimental studies, discussed previously, have illustrated that self-sacrificing contributions to public goods are chosen by most people.

\footnotetext{
${ }^{9}$ http://www.embraceitafrica.org/

10 To illustrate, the Heritage Foundation's Economic Freedom Index scores Uganda at 59.3 (out of 100) ranking it \#102 in the world scoring particularly low in Rule of Law (http://www.heritage.org/index/country/uganda). The Fraser Institutes' Economic Freedom of the World Index scores Uganda in it legal system/property rights at 4.7 (out of 10) ranking it \#104 in the world (Gwartney, Lawson, and Hall, 2015). The same individual, Youweri Museveni, has held power since 1986 and enjoys strong backing from the military.
} 
A common justification for this is to assume that there is a component to an individual's utility function that incorporates the well-being of others. These are typically referred to as social preferences (Fehr and Fischbacher, 2002). To illustrate, suppose an individual consumes $x$ of a private good and contributes $y$ to a public good. A selfish individual's utility can be represented by $u(x, y)$ where $x+y=I$ (where $/$ is income and, for simplicity, prices are normalized to one). An individual who has social preferences has a utility function of $u(x, y, z)$ where $z$ is the (non-excludable and non-rival) benefit others receive (rather, the "warm-glow" (Andreoni, 1995) from providing a public good that others enjoy). These social preferences, then, increase the marginal utility to contributing to the public good. Consequently, social preferences lead to higher levels of private, public good contributions.

Therefore, if exposure to trade leads individuals to have stronger social preferences (a greater value of $\partial u / \partial z$ adjusting the marginal rate of substitution between private and public good spending), then private contributions to public goods will be higher. There is reason to believe this is the case. For example, negative social interactions have been shown to lead to less pro-social behavior. Examples include violence from civil wars in Kenya (Becchetti, Conzo, and Romeo, 2014) and land re-allocation in Zimbabwe (Barr, 2003). Thus, if negative social interactions lead to lower levels of social preferences, then one can hypothesize that positive social interactions, such as mutually advantageous trade facilitated by microfinance, can lead to higher levels of social preferences. ${ }^{11}$

An alternative, but related, hypothesis is that microfinance works through income effects. If an individual's income increases, then regardless of the magnitude of the social preferences, since public goods are a normal good, one would realistically expect free riding to diminish. Microfinance is intended, specifically, to improve the income of the recipients. Thus, it seems reasonable to presume that receiving a microloan improves income, and that this leads an individual to contribute more to the public good.

A third theoretical argument is that of social norms. In this conceptual framework it is argued that individuals evaluate a strategic environment assessing what they believe the social norm is in the community. The social norm can be either the "empirical norm" of what is the typical response of many people or the "normative norm" of what an individual feels others believe should be decided (Bicchieri, 2006). ${ }^{12}$ An individual's decision, then, is to decide whether to engage in norm compliance, following his

\footnotetext{
${ }^{11}$ Relatedly, McCannon (2014) provides experimental evidence that those who have strong preferences for economic freedom (i.e., less government intervention in markets and improved enforcement of property rights) engage in pro-social behavior. Thus, positive opinions about markets correlate with pro-social behaviors.

12 In the literature, the term "injunctive norm" is used as a synonym for normative norm and "descriptive norm" is used for empirical norm.
} 
or her assessed social norm, or violate the norm. Individuals are "contingent cooperators" where they prefer to comply with the norm so long as they believe a sufficient number of other people are cooperating (Bicchieri, 2006).

Applying the theory of social norms, behavior is driven by an individual's expectations regarding others' decisions. Recent experimental evidence supports this framework. Bicchieri and Xiao (2007) consider giving in Dictator Games manipulating subject's empirical norms and normative norms and find that, when in conflict, individuals follow empirical norms. Krupka and Weber (2013) demonstrate that behavior in experiments can be predicted based on subject's normative norms. Likewise, Bicchieri and Chavez (2010) highlights the importance of normative norms in Ultimatum Game experiments. Reuben and Riedl (2008) investigate which social norm level of giving arises with punishment in public goods games, while Houser and Xiao (2011) demonstrate that public punishments are more effective and eliciting public goods contributions arguing that this is due to the impact on social norms. In a review of the literature on public goods experiments, Chaudhuri (2011) organizes evidence suggesting individuals behave as contingent cooperators.

This provides a third channel for microfinance to encourage pro-social behaviors. Microfinance loans lead an individual to engage in more mutually advantageous trade. If this exposure leads to an improvement in individual's expectations regarding the economic behavior of others, then these morepositive expectations can influence norm compliers to engage in more pro-social behaviors. In other words, if microfinance promotes trade by entrepreneurs, who generate a positive consumer surplus for others, then this can lead them to adopt positive-spillover activities as a social norm.

Related to our study, Gächter, Nosenzo, and Sefton (2013) design an experiment of a threeperson gift exchange. A principal pays a wage to two agents, who sequentially make effort decisions. A peer effect arises and the authors show that social preferences, rather than social norms, explain behavior. Thus, similar to this work, we differentiate between social norms and social preferences in explaining pro-social behavior.

Therefore, four alternatives are presented linking exposure to microfinance to pro-social behaviors. Either microfinance (1) directly influences social preferences, which cause pro-social behavior, (2) increases wealth, which causes an income effect increasing public good contributions, (3) improves social norms generating improved pro-social behaviors, or (4) has no effect on pro-social behaviors. $^{13}$

\footnotetext{
${ }^{13}$ Theoretical arguments of anti-social behaviors are not developed here. Karlan and Zinman (2011) include a survey of subjective well-being in their microfinance field study. Evidence suggests the possibility of microfinance
} 
Given the prevalence and important of microfinance efforts in economic development strategies and the competing theoretical arguments presented, a field study is designed. The field study implements a common laboratory experiment used to assess pro-social behaviors. The methods are designed to differentiate between the contrasting theories.

\section{Methods}

The description of the method employed in the experiment is separated into the major components. Namely, the setting, subjects, game, and procedures are explained.

\subsection{Setting}

The planning and implementation of the field study experiment was done with leaders of a U.S.based, non-profit organization Embrace It Africa (EIA). The organization operates primarily in the village of Bethlehem in the district of Rakai in Uganda. The Rakai district is at the southern edge of Uganda bordering Tanzania. Initially, the organization teamed up with a local, private boarding school, Bethlehem Parent's School (BPS), which has the mission of serving as an orphanage and primary school for children orphaned from the AIDS pandemic. BPS has expanded into pre-school and primary school services, along with enrolling non-orphaned children. EIA connects U.S. donors to BPS to fund school fees of orphans and finance building projects such as dormitories, teacher housing, and water wells, to name a few. EIA has now expanded into community health awareness and microfinance operations around the village of Bethlehem.

Importantly for this study, as previously described, EIA initiated its Mikwano Microfinance operations in 2008. EIA has constructed a building for its microfinance operations, which is located at the edge of the BPS school grounds. The experiment was conducted in this building.

Mikwano Microfinance and BPS are located in Bethlehem, which is a small village approximately 20 kilometers from the nearest small city of Kyotera (population of 7590 as of the 2002 Ugandan census). The area has an agriculture-based economy with bananas, coffee, maize, beans, and a variety of other vegetables as the primary sources of food. Subsistence agriculture dominates. Some families have chickens, goats, and pigs to provide eggs and meat. Only dirt roads provide access to the area.

crowding out family/community lending and, potentially, leading to lower well-being scores. Alternatively, Karlan and Zinman (2010) find improved subjective well-being scores. 


\subsection{Subjects}

Local community leaders and the administration of BPS were used to recruit experimental subjects. Advertising occurred throughout the entire village of Bethlehem at least one month prior to the event. Advertisements explained that professors would be conducting research in cooperation with Mikwano Microfinance and, therefore, help Mikwano better address the financial needs in the community. Announcements were made to parents of children at the school, at local churches, and other gatherings of village residents. Given the small population of the village, the employment of community leaders as recruiters lead to all members of the community being aware of the event. The experiments were conducted on January $11 \& 12,2016$. Any and all members of the community were invited to participate. The only restriction placed on the recruitment was that individuals had to be at least eighteen years of age to participate and they could take part in the study only once. Thus, we conducted a "framed field experiment" (Harrison and List, 2004), which are experiments that use a nonstandard subject pool and add a field context.

In Uganda, both English and the local language, Luganda, are official languages. Education occurs in English, but in rural communities Luganda dominates. The games and survey questions were asked in English and, if necessary, Luganda. Given the low expected literacy rates, printed instructions were not used. A script, though, was developed in both English (provided in the appendix) and Luganda to be used by the research team.

A total of 165 people participated in the experiment. On the first day, 107 subjects engaged in the experiment, with 58 subjects participating on the second day (the indicator variable Day 1 captures whether the subject engaged in the first day of the field study). In the experiment, $44.8 \%$ of the subjects were male. Subjects ranged in ages up to 76 years old. The average age was 33.31 with a standard deviation of 11.9 years and a median age of 30. The indicator variables Male and Age are included in the empirical analysis to control for gender and age effects.

On average, subjects had 8.03 years of school with a median of 7 and a standard deviation of 3.45. In Uganda, primary school lasts for seven years and secondary school lasts up to six additional years. A total of $11.3 \%$ of the subject pool had four or fewer years of school with $6.9 \%$ having zero years of schooling, but $42.5 \%$ completed more than the seven years of primary school. The variable Education, which is also included in the econometric model, counts the number of years of school completed. 


\subsection{Game}

Subjects played a standard, one-shot Public Goods Game. In it, each was endowed with 2500 Ugandan Shillings taking the form of five 500-Shilling coins. The coins were laid out on a bench in front of the subject. Each subject was instructed to choose how many coins to keep for him/herself and how many to put in a bucket, which was also placed on the bench. Subjects physically placed the coins in the bucket.

The subjects were instructed that they would be grouped with three other individuals participating in the experiment. Each would have the same decision to make. They were told that for every coin put in the bucket, the researchers would add another coin. After the four had made their decision and the coins had been added, the amount in the bucket would be evenly divided between the four of them.

After making their choice, two additional questions were asked. First, subjects were asked "how many coins do they believe individuals will typically put in the bucket." Again, a whole number between zero and five was provided by each respondent. Second, the subjects were asked to suppose, "they were the only one of the four who was allowed to put coins in the bucket." It was followed with the reinforcement that whatever they put in the bucket would be matched, but also evenly shared amongst the four in the group. They were asked in this scenario how many coins they would like to have put in the bucket.

The first question is designed to elicit the empirical norm held by the subject. Rather than have the individual anticipate the exact behavior of the people s/he will be paired with, the question asks individuals to provide information regarding his or her beliefs about the typical person. In this way, we can evaluate whether a subject is complying with the social norm. This allows us, within a pool of subjects who make differing public goods contributions, whether they differ in their expectations regarding the norm of play or they differ in their actual willingness to break with the norm.

The second question was designed to record subject's decision in the Dictator Game (Kahneman, Knetsch, and Thaler, 1986). The Dictator Game is a common tool to assess an individual's level of altruism/fairness. In it, subjects are asked to make a contribution from their endowment. The contribution benefits others, but comes at a personal cost. What differentiates the Dictator Game from other games of social-preference elicitation is that the recipients of the contribution have no action to take. Thus, issues such as reciprocation cannot influence behavior. While numerous studies have directly investigated the determinants of Dictator Game giving, it is most commonly used as a subject-level 
control variable. For example, Cox (2004) argues for a triadic experimental structure when studying Trust Games. Contributions in games intended to assess pro-social behaviors can either be driven by a preference to share (altruism) or based on a strategic motivation to grow wealth and benefit through others' motivation to reciprocate. In public goods environments, a subject may want to share with others, which is a different motivation than matching the behavior of others. Hence, the amount offered as a response to the second question can be used to differentiate the motives of the subjects in the Public Goods Game.

The standard design for a Dictator Game is to consider a two-person group where one of the subjects can give to the other (see List (2007) for an analysis of the game). We choose to consider a fourperson grouping to keep the decision problem as similar as possible to the Public Goods Game implemented. One should always be concerned whether the subjects understand the decision problem they have, so that choices driven by confusion does not confound the results (Andreoni, 1995). Therefore, the decision problem we provided incorporates self-sacrificing decision making without deviating far from the public goods choice problem. The difference between the two problems we present the subjects is only whether others can contribute, which is the crucial distinction between free riding behavior and non-altruistic behavior.

Consequently, three measurements arise from the experiment. The amount actually given in the Public Goods Game becomes the observation for the variable Contribution. The amount expected of others is the variable Norm. Finally, the amount given when they were the only one who could give makes the variable Dictator. Each variable takes a discrete value between zero and five.

\subsection{Procedure}

To staff the experiments leaders of the school and both co-authors ran the sessions. Local Ugandans with high levels of education and proficiency in English were used as translators. At all times at least four translators were available. English was used, and a Luganda translator was available to assist each subject in conducting the experiment. Furthermore, prior to date of the study, a script was written and translated into Luganda. An English copy of the script is in the appendix. Aids were trained prior to the experiment.

To provide a "show-up" compensation for participation, rather than give money, we provided a community meal both days. Everyone was welcome to come and eat a traditional Ugandan meal. Culturally, food is expected at any sort of community function, and so by abiding by cultural norms, we 
were able to recruit many people for the experiments. Volunteers from the community were utilized to cook and serve the food. These volunteers are closely affiliated with BPS, being either teachers or former students who still live in the community. Since all schools were on break for the month of January, many people were willing and eager to volunteer their time.

Tents were set up outside the microfinance building. To entertain community members and commence the event, young BPS students performed traditional songs and dances. Members of the community were free to come and eat and bring their family, without an obligation to participate in the experiment. If they wanted to also engage in the experiment, they were encouraged to enter the building. Once inside, consent forms were provided and explained (and signed).

After providing written, informed consent, the subject went to one of two small rooms inside the building where the game was played. In each room was a bench with five coins laid out and a bucket. Subjects physically placed the coins in the bucket. Only one subject was in a room with the researcher and translator at a time, and the door was shut during the game to ensure the confidentiality of the responses.

After completing the game, the subject went to a second room within the building to complete a survey. A copy of the survey is provided in the appendix. Descriptive statistics from the survey are provided in the following section.

Finally, a desk in the main room of the building was used to provide payment. After completing the survey, each subject came one at a time to the desk. To score the game, a rolling average was utilized. A subject's contribution was added to the contributions of the three previous participants to determine the subject's earnings. Since the game was one-shot, each subject earned the amount from the game. Given that each starts with an endowment of 2500 Ugandan Shillings (hereafter UGX), and there is no deadweight loss to the game, the average payment could not be less than 2500 UGX. If each subject made a full five-coin contribution, then the average payment could be as high as 5000 UGX. For a subject, the lowest monetary payment possible would occur if $s /$ he contributed everything and was paired with three others who contributed nothing. This would result in a payment of 1250 UGX (but this outcome did not happen to occur). Additionally, the maximum payment a subject could have received arises if $s /$ he contributes nothing, but the other three make a full contribution. This would generate 6250 UGX (again, this did not arise). Since the 500-Shilling coin was the smallest denomination used in the sessions, payments were rounded up to the nearest 500 UGX. The average monetary payment earned was 4293.90 UGX, ranging between 2500 and 6000 UGX with a median of 4000 and a standard deviation of 1040.30 . 
In the local community it was learned, during a pre-experiment assessment, that the typical wage for a person hired as a (unskilled) laborer was 2500 to 4000 Ugandan Shillings for a day's work. Thus, the endowment in the game represents approximately a day's salary for a low-skilled, temporary worker and subjects earned 1-1.5 days salary. Thus, it can be argued that not only was the compensation appropriate, but real stakes were at play. ${ }^{14}$ The exchange rate between the Ugandan Shilling and the U.S. Dollar was approximately 3000 UGX per $\$ 1$. Thus, the average payment was $\$ 1.43$.

\section{Descriptive Findings}

First, the descriptive statistics from the variables used from the background survey are presented. Table 1 provides the variables used in the empirical analysis (other than the background controls already described in Section 3.2). ${ }^{15}$

\footnotetext{
${ }^{14}$ Anecdotal evidence supports this. An issue that arose on the second day was that two individuals were caught trying to play the game a second time. One subject went home and changed clothes while another attempted to hide her face in the hope of being assigned to the other room to play the game, getting a new researcher and translator that did not recognize her. Thus, the stakes were high enough to encourage such attempts. ${ }^{15}$ The standard deviation of Farm: \#Work, Farm: \#Chick, and Labor: \#Work is 1.80, 79.78, and 2.22 respectively with maximum values of 10,500 , and 9.
} 


\begin{tabular}{|c|c|c|c|}
\hline Variable & Description & $\%$ of sample & \# Obs. \\
\hline Microfinance & $=1$ if subject had received a microloan & $40.0 \%$ & 165 \\
\hline \multicolumn{4}{|l|}{ Occupations } \\
\hline$\overline{\text { Farmer }}$ & $=1$ if self-identified as a farmer & $61.0 \%$ & 165 \\
\hline Trader & $=1$ if self-identified as a trader/businessman & $21.8 \%$ & 165 \\
\hline Teacher & $=1$ if self-identified as a teacher & $12.7 \%$ & 165 \\
\hline Student & $=1$ if self-identified as a student & $3.6 \%$ & 165 \\
\hline Boda & $=1$ if self-identified as a boda-boda driver & $2.4 \%$ & 165 \\
\hline Skill & $=1$ if self-identified with a skilled occupation & $11.5 \%$ & 165 \\
\hline \multicolumn{4}{|l|}{ Wealth } \\
\hline$\overline{\text { Concrete }}$ & $=1$ if subject's house has a concrete floor & $57.7 \%$ & 161 \\
\hline Kuywepe & $=1$ if subject's house is made of mud & $19.8 \%$ & 162 \\
\hline Electricity & $=1$ if subject's house has electricity & $20.8 \%$ & 154 \\
\hline Solar & $=1$ if subject's house has solar power & $9.8 \%$ & 154 \\
\hline \multicolumn{4}{|l|}{ Income } \\
\hline$\overline{\text { Farm: Work }}$ & $=1$ if subject is a farmer and employs workers & $55.0 \%$ & 165 \\
\hline Farm: \#Work & \# of workers employed by a farmer & 3.11 & 165 \\
\hline Farm: Crops & $=1$ if subject is a farmer and grows crops & $95.0 \%$ & 165 \\
\hline Farm: Live & $=1$ if subject is a farmer and has livestock & $81.0 \%$ & 165 \\
\hline Farm: Cows & $=1$ if subject owns at least one cow & $21.0 \%$ & 165 \\
\hline Farm: \#Chick & \# of chickens owned by a farmer & 12.23 & 165 \\
\hline Trader: Work & $=1$ if a subject is a trader and employs workers & $52.8 \%$ & 165 \\
\hline Trader: \#Work & \# of workers employed by a trader & 3.45 & 165 \\
\hline
\end{tabular}

Overall, $40 \%$ of the subjects received a microfinance loan. The survey asks participants to identify which lending organization provided the funding. As described, a number of microfinance operations in the area (four are identified by our subjects). Thus, the number of subjects receiving any one particular microloan is small (see Table A1 in the appendix for a breakdown). Only the coarser Microfinance variable is studied here. Furthermore, we do not differentiate SACCOs from MFIs here. 
The second set of variables are occupation controls. They sum to a number greater than $100 \%$ because individuals can have two jobs. For example, a teacher can also engage in farming ${ }^{16}$ or a person can divide his or her time between farming and selling goods in a shop. A majority of the subjects report some degree of farming. A small cohort of the sample involves subjects who have what one might consider a high-skill job. Occupations reported include being a security guard, mechanic, or a manufacturer of alcohol in a distillery. A small proportion of the sample are boda-boda drivers, which are individuals who have a motorcycle and receive income from driving others on their bikes (i.e., taxi service).

To capture wealth levels, the amenities of their living environment is recorded. Banking services are not readily available and many transactions occur through barter exchanges. Hence, physical surroundings is used as a proxy for wealth. A slight majority of the individuals, for example, have a solid floor in their house, with over two-fifths having only dirt floors. Approximately $20 \%$ of the sample live in mud huts leaving $80 \%$ to have brick houses. Electricity and solar power are rare. For about $70 \%$ of the subjects no form of power is available at their house. Therefore, one can argue that a relatively wealthy family lives in a brick house with a cement floor having electricity. Only $18.3 \%$ of the sample lives in this type of an environment where $12.4 \%$ of the subjects have none of these features. ${ }^{17}$

The income-related measurements are also included. It was anticipated that the vast majority of subjects were either farmers or traders. Thus, the controls are designed with the subject being a farmer (or trader for the last two). Conditional on being a farmer, just over one-half employ a laborer for at least part of the season and, when they do hire, employ over three workers. Given the subsistence agriculture lifestyle, almost all reported farmers grow crops and many have livestock. The most popular crops grown are beans, maize, and bananas. Some subjects also grow coffee, cassava, and ground nuts (to name a few). Most who have livestock have goats and chickens. Only $21 \%$ of those reporting the ownership of livestock have cattle, and no one has more than ten cows. While most subjects have chickens, the average number of chickens owned is approximately a dozen. There is substantial heterogeneity though. While the median number of chickens is eight, one subject reported owning 500 chickens while another owns 100 . Therefore, it is expected that a farmer has a higher income if $s /$ he

\footnotetext{
${ }^{16}$ For example, one charitable intervention by EIA was to raise funds to provide teachers with a pig. The school suffers from cash-flow problems and, occasionally, is unable to meet the monthly payroll. The pigs reproduce and the piglets can be sold to provide an income during such disruptions. Also, it would not be uncommon for a family to have a little bit of land next to their house where they plant a small amount of vegetables for food.

${ }^{17}$ Missing observations exist for these wealth variables. Members of the research team were repeatedly reminded that participation was voluntary and that if a subject did not feel comfortable answering a question they were free to not answer. The research team was not to press for information.
} 
employs other workers, owns cattle, or has a larger number of chickens (where eggs can be sold for cash). A more detailed breakdown of livestock and crops is given in Table A2 in the appendix. Regarding traders, about one-half employ workers and when they do they hire about three and a half. Again, a trader is expected to be of higher income if more workers are employed.

Turning to the resulting play in the games, Table 2 presents a summary of the outcomes. The variables are measured in the number of coins (500 Ugandan Shillings pieces) out of the five coin endowment.

TABLE 2: Summary of the Outcomes of the Experiment

\begin{tabular}{llllll}
\hline & Mean & Median & Std. Dev. & Min & Max \\
\hline Contribution & 3.139 & 3 & 0.99 & 1 & 5 \\
Norm & 2.986 & 3 & 1.05 & 1 & 5 \\
Dictator & 3.421 & 4 & 1.07 & 1 & 5 \\
Pot & 12.26 & 13 & 2.63 & 4 & 18 \\
Earnings (coins) & 7.98 & 8 & 1.25 & 5 & 12 \\
$\quad$ (Ugandan Shillings) & 3987.90 & 4000 & 623.36 & 2500 & 6000
\end{tabular}

Overall, subjects contributed $62.8 \%$ of their endowment to the public good. This amount is higher than what is typically observed in public goods experiments (Ledyard, 1995). This, though, can be due to age, education, income, or cultural differences. It is not possible to disentangle the specific differences in the populations, but previous work suggests all are important. For a point of reference, evacuees of hurricane Katrina gave approximately $40 \%$ of their endowment in a public goods field study. Additionally, their behavior exceeds their expectations of others, on average. Subjects actually contribute $5.1 \%$ more than they expect others to give. Again, this differentiates the subject pool from the typical experiment using U.S. undergraduates. Third, giving in the Dictator Game is substantially higher than in the Public Goods Game. Once again, this is different than previous studies where Dictator Giving is typically one-half of the public goods giving. Fafchamps and Hill (2015) also conducts an experiment with Ugandan farmers. They find that the rate of giving in a Dictator Game is substantially higher for the Ugandans than for western, university students (Oxford). Thus, the behavior of the less- 
educated, older Ugandans is distinct, but consistent with previous findings. Interestingly, no subject engaged in complete free riding or expected others to do so. Again, this differs from more typical experimental subject pools where full free riding can be expected to occur in $15-25 \%$ of the observations. To explore these factors further, Table 3 presents correlation coefficients between variables of interest.

Table 3: Correlation Coefficients

\begin{tabular}{|c|c|c|c|}
\hline & Contribution & Norm & Dictator \\
\hline Norm & $0.33 * * *$ & & \\
\hline Dictator & $0.59 * * *$ & $0.17 * *$ & \\
\hline Male & $-0.16 * *$ & -0.06 & $-0.15 *$ \\
\hline Age & -0.06 & 0.01 & -0.10 \\
\hline Education & 0.09 & 0.02 & 0.05 \\
\hline Microfinance & $0.16^{* *}$ & $-0.13 *$ & 0.01 \\
\hline
\end{tabular}

Within the Ugandan population considered, education and age do not correlate with behavior. Gender and exposure to microfinance loans do. The former is of primary interest here. As to be expected, expectations and contributions, both altruistic and public goods contributions, are highly correlated.

The primary, anticipated finding is that microfinance exposure, which is argued here to have the spillover effect of promoting social preferences, is correlated with increased public goods contributions. Figure 1 compares the subsample of the population who has previously received a microfinance loan to the subsample who have not for the three outcome variables. 
Figure 1: Comparison of Recipients of Microloans

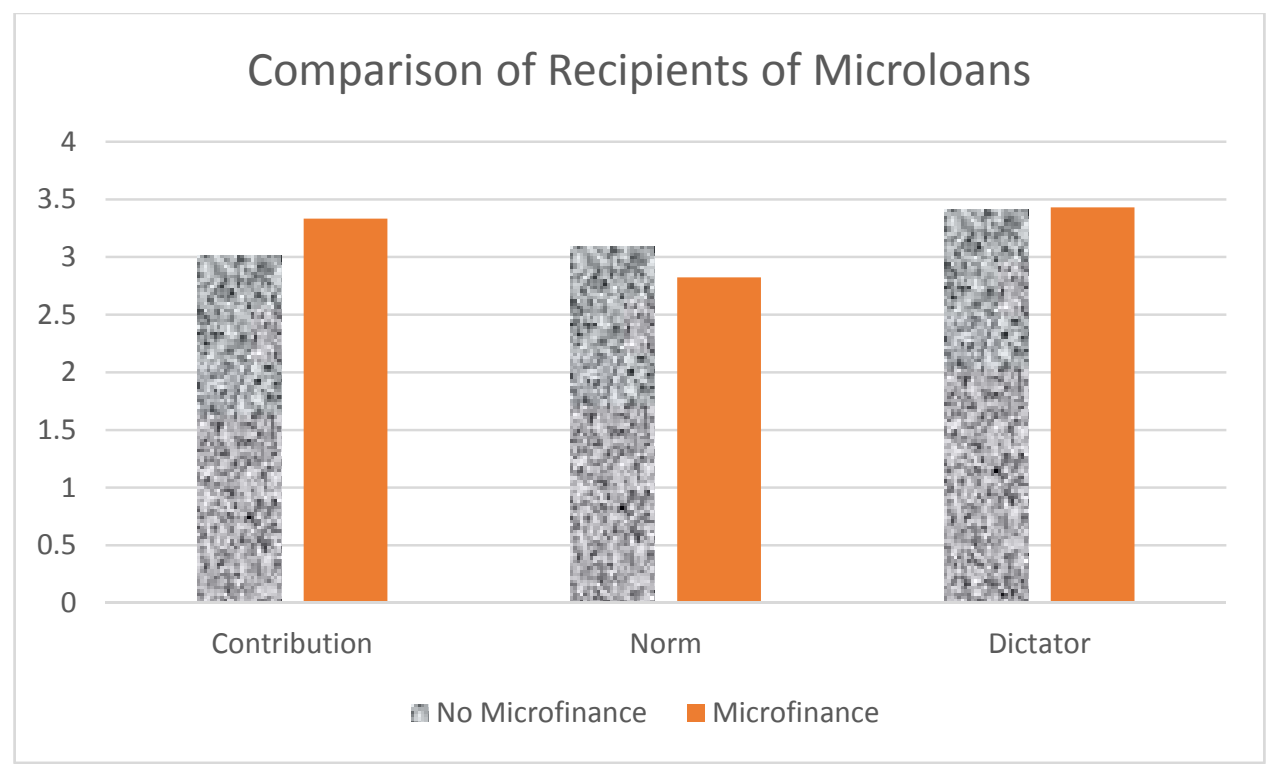

Comparing the subsample of research subjects who have received a microfinance loan to those who have not, past recipients make larger public goods contributions. The former contribute on average 0.32 more coins (rather, 162 UGX), which represents a $10.7 \%$ increase. Another way to compare the two groups is to consider the proportion that contribute four or five coins. For those who have received a microloan, $47.0 \%$ make such a contribution, while for those who have not, only $34.3 \%$ give four or five. This suggests that there is an important, positive relationship between access to microfinance and prosocial behaviors.

As a counterfactual, information was also collected from each subject asking whether or not they had received in the past a loan from a bank. For the sample, $75.6 \%$ of the subjects had not received a bank loan. Comparing the sample of those who have received a bank loan to those who have not, little difference arises. Individuals who have received a bank loan contribute, on average, 3.13 coins, while those who have not contribute, on average, 3.14 coins (for a difference of 9.5 UGX, or rather, \$0.003). Therefore, the enhanced contributions of those with microfinance loans is not replicated by those with standard bank loans.

Alternatively, individuals who have been past recipients of microloans have lower expectations regarding typical pro-social behavior in their community. On average, the empirical norm is $8.8 \%$ lower. Thus, past recipients of microfinance loans free ride less, but expect others to do so more. 
Interestingly, the altruistic contributions in the Dictator Game are substantially higher for both populations than in the Public Goods Game. There is not any noticeable difference between the altruistic giving of those who have received a microloan from those who have not. Thus, the discrepancy in play is focused on whether others can (and are expected to) contribute, rather than selfless choices.

While there is evidence that microfinance correlates with behavior and expectations, it is important to assess the relationship between these behaviors. Figures 2 and 3 compare the average amount contributed to the public good by subsamples. The subsamples considered in Figure 2 are the levels of social norms, or rather, the amount a subject believes others will typically give.

Figure 2: Average Amount Contributed for Each Level of Norm

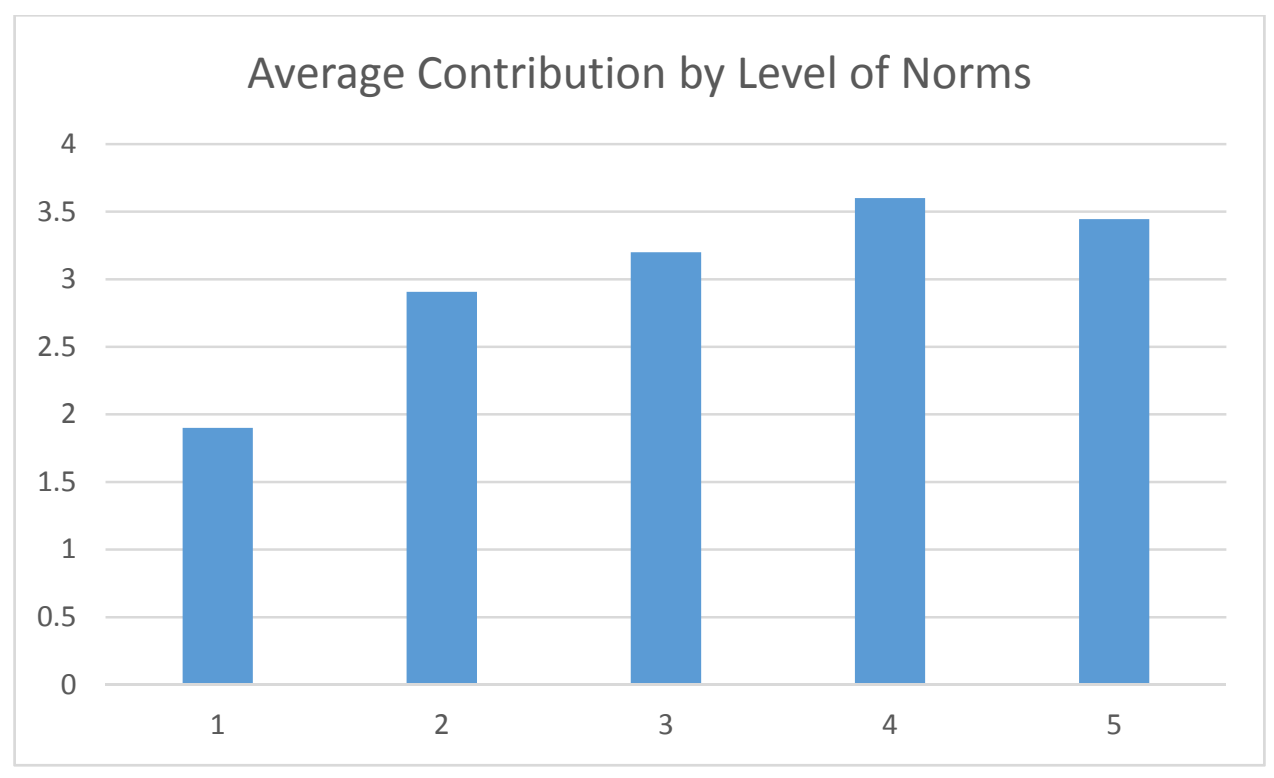

As one can see, those who have expectations that others will typically give more (x-axis) frequently contribute more themselves ( $y$-axis). This suggests that the population studied, overall, engages in contingent cooperation. One who expects others typically contribute all five give 2.22 times as much as those who believe others typically give only one. Notice, though, that those who have optimistic expectations of others give less than they believe the norm is. Alternatively, those with a more pessimistic view of the norm of behavior of others exceed this standard.

Figure 3 considers subsamples by the amount given in the Dictator Game. 
Figure 3: Average Amount Contributed for Each Level of Dictator Giving

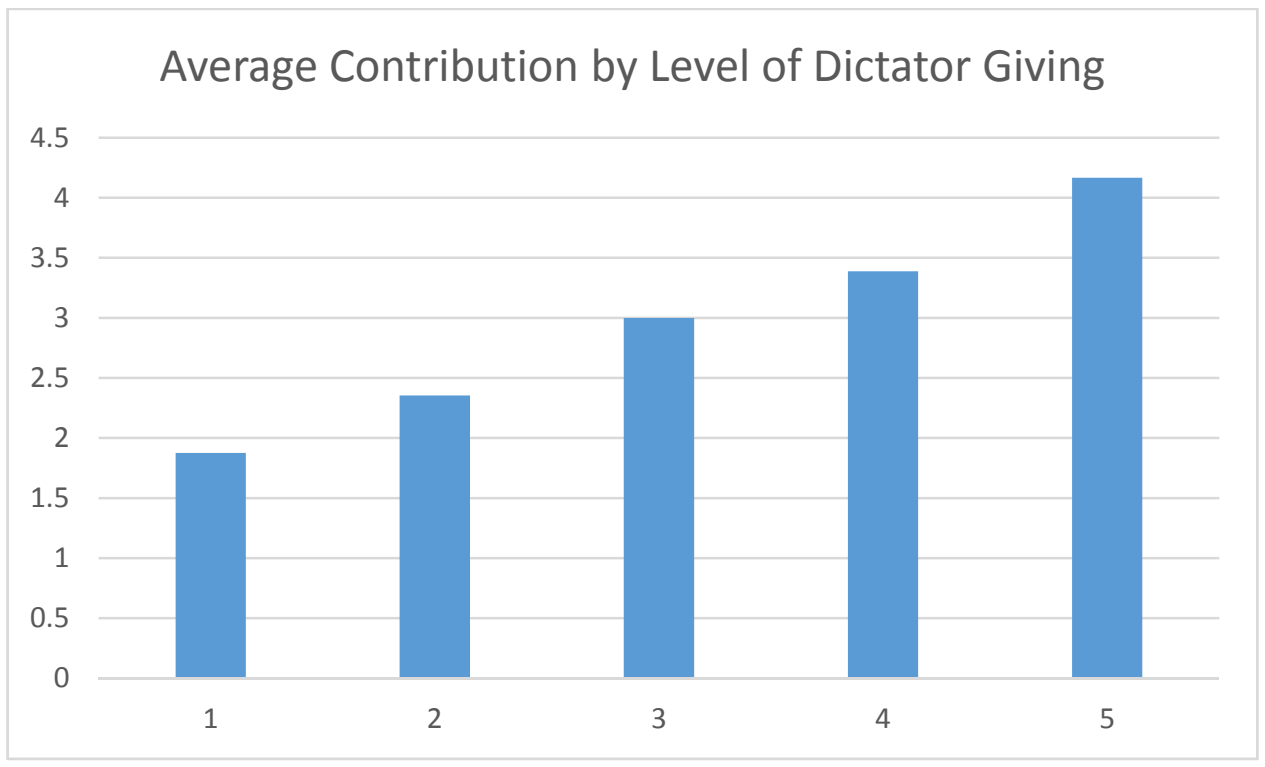

Again, as to be expected, a strong relationship is observed between the two. Those who are willing to give more to others are willing to contribute more to the public good themselves. Interestingly, the average amount contributed is more than the Dictator Game giving for those who give only one or two in it, exactly the same for those who give three, and less for those who give either four or five in the Dictator Game. This suggests a non-constant relationship. Those who have strong altruistic preferences are willing to ramp up their giving when they are the only ones who can give. Those who are less altruistic are unmotivated to give when they are the only one, but give relatively more when others can also give. This also, again, suggests that the ability of others to contribute is important for many subjects.

\section{Econometric Results}

The descriptive results suggest that there is a strong relationship between access to microfinance loans and the pro-social behavior of contributing to a public good. Furthermore, the public good contributions are correlated with empirical social norms and altruistic giving. A formal investigation is needed to separate these effects and identify the channel through which microfinance 
affects pro-social behaviors. To do so, the data collected from the field study experiments is used to estimate the following econometric model,

$$
\text { Contribution }_{i}=\beta_{0}+\text { Microfinance }_{i} \beta_{1}+X_{i} \beta_{2}+\varepsilon_{i}
$$

where $X_{\mathrm{i}}$ is a vector of individual-specific control variables, which in the econometric investigation will be controls for backgrounds, occupations, wealth, income, norms, and altruism.

Table 4 presents the main results. Specifications with differing sets of control variables are presented to differentiate direct versus indirect effects. Robust standard errors are presented in parentheses. 
TABLE 4: Microfinance and Public Goods Contributions (OLS, dependent variable $=$ Contribution)

\begin{tabular}{|c|c|c|c|c|}
\hline & I & II & III & IV \\
\hline Microfinance & $\begin{array}{l}0.323 * * \\
(0.150)\end{array}$ & $\begin{array}{l}0.277 * \\
(0.160)\end{array}$ & $\begin{array}{l}0.379 * * * \\
(0.128)\end{array}$ & $\begin{array}{l}1.073 * * \\
(0.451)\end{array}$ \\
\hline Norm & & & $\begin{array}{l}0.285 * * * \\
(0.065)\end{array}$ & $\begin{array}{l}0.312 * * * \\
(0.080)\end{array}$ \\
\hline Micro x Norm & & & & $\begin{array}{l}-0.081 \\
(0.129)\end{array}$ \\
\hline Dictator & & & $\begin{array}{l}0.502 * * * \\
(0.067)\end{array}$ & $\begin{array}{l}0.563 * * * \\
(0.093)\end{array}$ \\
\hline Micro x Dictator & & & & $\begin{array}{l}-0.132 \\
(0.132)\end{array}$ \\
\hline Male & & $\begin{array}{l}-0.368 * * \\
(0.183)\end{array}$ & $\begin{array}{l}-0.092 \\
(0.136)\end{array}$ & $\begin{array}{l}-0.090 \\
(0.137)\end{array}$ \\
\hline Age & & $\begin{array}{l}-0.003 \\
(0.007)\end{array}$ & $\begin{array}{l}0.0002 \\
(0.0052)\end{array}$ & $\begin{array}{l}2.5 \times 10-5 \\
(0.005)\end{array}$ \\
\hline Education & & $\begin{array}{l}0.035 \\
(0.030)\end{array}$ & $\begin{array}{l}0.007 \\
(0.021)\end{array}$ & $\begin{array}{l}0.008 \\
(0.021)\end{array}$ \\
\hline Day 1 & & $\begin{array}{l}0.191 \\
(0.167)\end{array}$ & $\begin{array}{l}-0.079 \\
(0.132)\end{array}$ & $\begin{array}{l}-0.079 \\
(0.133)\end{array}$ \\
\hline constant & $\begin{array}{l}3.010 * * * \\
(0.098)\end{array}$ & $\begin{array}{l}2.872 * * * \\
(0.434)\end{array}$ & $\begin{array}{l}0.409 * * * \\
(0.352)\end{array}$ & $\begin{array}{l}0.122 \\
(0.393)\end{array}$ \\
\hline Occupation & NO & {$[0.85]$} & {$[1.50]$} & [1.40] \\
\hline adjusted $R^{2}$ & 0.020 & 0.030 & 0.451 & 0.452 \\
\hline AIC & 462.6 & 450.6 & 360.6 & 362.3 \\
\hline $\mathrm{F}$ & $4.3 * * *$ & $2.19 * *$ & $17.8^{*}$ & $16.9 * * *$ \\
\hline$N$ & 165 & 159 & 158 & 158 \\
\hline
\end{tabular}


The positive and statistically significant coefficient of Microfinance provides the main result and conform to the descriptive findings presented in Figure 1. Those who have received microfinance loans in the past make greater public goods contributions. Without any controls, the impact is to increase giving by $10.3 \%$ at the mean, with an increase to $12.1 \%$ (rather, 0.4 of a standard deviation) once the characteristics of the decisionmaker, norms, and altruism are controlled for (column III).

One proposed channel through which microfinance can operate is through norms. To disentangle a direct effect on giving to the public good from an indirect effect through adjusting norms of behavior, column III and IV includes the expectations and altruistic giving of the subjects. While III adds them as control variables, IV allows for an interaction effects. Microfinance continues to have an independent effect on public goods donations. Thus, receiving a microloan in the past has a direct effect on one's willingness to contribute, but not necessarily an indirect effect through its impact on anticipated, empirical norms and altruistic giving. Adding the interaction terms between Microfinance and Norm, as well as, Dictator suggests that while each has an intercept shift up in the giving level, there is not a strong interaction effect.

Consistently across the specifications, age, education, and occupations are unrelated to free riding. There is some evidence that gender matters as males gives less. This is consistent with the simple correlations in Table 3. This coefficient, though, loses its statistical significance once norms and altruistic preferences are included. Men tend to have lower expectations regarding others' typical play, and contribute less in the Dictator Game. These attributes explain giving.

The inclusion of social norms and altruistic preferences reveal that they have a statisticallysignificant, positive relationship with public goods contributions. Those who believe individuals typically give more also contribute more. The coefficient estimated is less than one, though. This suggests that there is free riding on the social norm in that each coin a subject expects out of others, his or her giving increases by only one-fourth of a coin. Those who are more willing to give even when others cannot, give more. Again, the estimated marginal effect is less than one. This suggests some free riding off of others. Given a subject's level of altruism, giving is shaded down due exclusively to the fact that others are able to contribute. This conforms to the observations presented in Figure 3.

The results presented are robust to changes in the specification. If either the occupation variables or the controls are omitted, the sign and statistical significance of Microfinance, Norm, and Dictator remain. Also, their statistical significance is retained if alternative standard errors are calculated such as unadjusted standard errors or those clustered by experimental day. Additionally, the dependent variable takes on only discrete values of $1,2,3,4$, or 5 . Both an ordered probit model and a Poisson 
Count Data model are estimated. The three main variables of interest all retain the sign and statistical significance.

The previous results present strong evidence that microfinance loans impact free riding behavior. One important channel that this can work through, as discussed, is social norms. In the theory of social norms, as summarized in Section 3, individuals form empirical expectations of what others will do. They have a preference for complying with the norm, or rather, they are willing to contingently cooperate if they believe a sufficient number of others are adopting a social norm of cooperation (Bicchieri, 2006). If exposure to microfinance loans simply improves social norms, then there should be no change in the likelihood a subject is willing to exceed, match, or fall short of his or her assessed social norm. Alternatively, if microfinance loans have a direct impact on pro-social preferences, then an adjustment in play, relative to the subject's own reported expectations, will be observed.

To conduct this additional test of the role of social norms, the variable Exceed is defined to equal one if and only if Contribution > Norm. Similarly, the variable Match equals one if and only if Contribution $=$ Norm. Furthermore, the hierarchical variable Order is equal to two if Exceed $=1$, equal to one if Match $=1$, and is zero otherwise. In the population studied, $31 \%$ have Match $=1$ and $43 \%$ have Exceed $=1$, leaving $26 \%$ to contribute less than they expect out of others.

Binary logit models are estimated with Exceed and Match as the dependent variable. Furthermore, an ordered logit with Order as the dependent variable is estimated. Robust standard errors are presented in Table 5 in parentheses and marginal effects at the mean are presented in curly brackets. The controls, occupation variables, and wealth/housing assessments are included, but not presented, in Table 5. 


\begin{tabular}{|c|c|c|c|}
\hline & $\begin{array}{l}\text { Exceed } \\
\text { (Binary Logit) }\end{array}$ & $\begin{array}{l}\text { Match } \\
\text { (Binary Logit) }\end{array}$ & $\begin{array}{l}\text { Order } \\
\text { (Ordered Logit) }\end{array}$ \\
\hline Microfinance & $\begin{array}{l}1.089 * * *\{0.264\} \\
(0.411)\end{array}$ & $\begin{array}{l}-0.482\{-0.097\} \\
(0.428)\end{array}$ & $\begin{array}{l}1.005 * * \\
(0.392)\end{array}$ \\
\hline Dictator & $\begin{array}{l}0.660 * * *\{0.162\} \\
(0.207)\end{array}$ & $\begin{array}{l}-0.141\{-0.029\} \\
(0.204)\end{array}$ & $\begin{array}{l}0.666 * * * \\
(0.168)\end{array}$ \\
\hline Controls & YES & YES & YES \\
\hline Occupations & YES & YES & YES \\
\hline Wealth & YES & YES & YES \\
\hline McFadden $\mathrm{R}^{2}$ & 0.177 & 0.151 & --- \\
\hline AIC & 198.5 & 188.4 & 309.1 \\
\hline$\%$ correct & $70.7 \%$ & $74.1 \%$ & $53.1 \%$ \\
\hline $\mathrm{N}$ & 147 & 147 & 147 \\
\hline
\end{tabular}

Those who have received microfinance loans are much more likely to contribute more to the public good than they expect others will typically give. Rather, they exceed what they expect out of others. The estimated marginal effect is an increase in the probability by 26.4 percentage points, or rather, an increase in the rate by $85 \%$. There is no difference between the likelihood of matching their empirical expectations of others from non-recipients. Thus, this is further evidence that exposure to microfinance improves pro-social preferences and, consequently, behaviors directly. The effect does not channel exclusively through more optimistic, positive social norms.

While microfinance can encourage more pro-social behavior by facilitating social preferences (and, as illustrated, not necessarily through social norms), what is unexplored in the previous analysis is potential income and wealth effects. One would expect that an individual who is relatively wealthier with a higher income would, due to the diminishing returns to consumption of private goods, be more willing to contribute to a public good. Microfinance is intended to build up wealth and expand income. 
Thus, one would like to assess whether the improved pro-social behaviors of those who have received microfinance loans are working strictly through income effects.

To address this, first the housing controls are included. They are intended to capture wealth. Individuals who have higher wealth are expected to have a better living arrangement, which would be represented by the physical structure and access to power. Second, the numerous income measurements are included. For farmers their ability to employ workers and own livestock is included. Additionally, as argued, the ownership of cattle and the number of chickens captures increased incomes. For traders, the ability to employ laborers signals higher income.

Table 6 presents the results adding the wealth and income controls to the baseline model (column III, Table 4). Again, robust standard errors are presented in parentheses. 
TABLE 6: Income and Wealth

(OLS, dependent variable $=$ Contribution)

\begin{tabular}{|c|c|c|c|c|}
\hline Microfinance & $0.391 * * *$ & (0.129) & $0.387 * * *$ & (0.129) \\
\hline Norm & $0.254 * * *$ & $(0.067)$ & $0.253 * * *$ & $(0.070)$ \\
\hline Dictator & $0.478 * * *$ & $(0.071)$ & $0.480 * * *$ & $(0.074)$ \\
\hline Concrete & -0.198 & (0.134) & -0.177 & (0.144) \\
\hline Kuywepe & 0.149 & $(0.138)$ & 0.136 & $(0.142)$ \\
\hline Electricity & -0.179 & $(0.162)$ & -0.207 & $(0.176)$ \\
\hline Solar & -0.277 & $(0.272)$ & -0.341 & $(0.297)$ \\
\hline Farm: Work & & & -0.177 & (0.197) \\
\hline Farm: \# Work & & & 0.019 & $(0.043)$ \\
\hline Farm: Crops & & & 0.099 & $(0.192)$ \\
\hline Farm: Live & & & 0.135 & (0.169) \\
\hline Farm: Cows & & & -0.068 & $(0.228)$ \\
\hline Farm: \#Chick & & & -0.0004 & (0.0008) \\
\hline Trader: Work & & & 0.025 & $(0.273)$ \\
\hline Trader: \#Work & & & 0.004 & (0.039) \\
\hline constant & $0.574 * * *$ & $(0.378)$ & 0.421 & $(0.416)$ \\
\hline Occupation & [1.36] & & [1.13] & \\
\hline Controls & {$[0.41]$} & & {$[0.04]$} & \\
\hline $\operatorname{Adj} R^{2}$ & 0.459 & & 0.430 & \\
\hline AIC & 331.4 & & 345.6 & \\
\hline $\mathrm{F}$ & $14.9 * * *$ & & $9.9 * * *$ & \\
\hline$N$ & 147 & & 147 & \\
\hline \multicolumn{5}{|c|}{$\begin{array}{l}\text { Heteroscedasticity-robust standard errors presented in parentheses. } \\
\text { F-stat for joint significance reported in brackets. } \\
\text { trols include indicator variables Farmer (omitted), Trader, Teacher, Student, Boda, and Skill. } \\
\text { Controls include Male, Age, Education, and Day 1. }\end{array}$} \\
\hline
\end{tabular}

To address the concern regarding income and wealth, numerous related control variables are included. The first set are those related to current living conditions (i.e., wealth). Each living environment-related question is individually statistically-insignificant and they are jointly insignificant. ${ }^{18}$

\footnotetext{
18 If the variables Microfinance, Norm, and Dictator are excluded, the existence of a concrete floor has a negative and statistically significant correlation with Contribution. Additionally, the wealth controls are collectively significant (F-stat $=2.01$ ) at the $10 \%$ level (but not $5 \%$ level). Similarly, the income controls continue to be
} 
Additionally, the second set of controls include measurements of income such as whether an individual employs workers, has at least one cow, and the number of chickens (conditional on having cows and chickens, respectively). Again, individually and collectively, the income variables are statistically independent from free riding. Importantly, the sign and statistical significance of previous access to microfinance loans is unchanged. Thus, microfinance's impact on pro-social behavior is independent of income and wealth.

As noted in Section 2, there are multiple nonprofit organizations providing microfinance loans in the Rakai district of Uganda. The analysis presented here does not differentiate behavior by source of funding. Such a comparison is presented in Table A1 in the appendix. Summarizing, behavior is consistent across recipients from the various organizations. Contributions made by microloan receivers are above the Microfinance $=0$ subsample for every organization. Similarly, expectations of others are consistently below the comparison group. Thus, the results are not driven by the methods employed by one particular non-profit organization.

The results presented in Tables 4, 5, and 6 demonstrate that microfinance loan recipients contribute more to the public good, and that this effect cannot be attributed to changes in social norms or income and wealth. The presumption, then, is that its effect occurs through an adjustment in individual preferences. One should be concerned, though, that there is not a direct effect of microfinance exposure on preferences, but rather selection effects drive the results. In other words, the characteristics of individuals that qualify them for seeking and receiving a microloan are those traits that also lead an individual to avoid free riding.

To address this concern, we first compare the sample of those who have received a microloan from those who have not. Table 7 presents the comparisons. The final column presents the t-statistics from an (unbalanced) difference in means test.

individually and collectively insignificant. Also, if the two interaction terms are included into the specification in column II, they are each statistically insignificant. 
TABLE 7: Subsample Comparisons

\begin{tabular}{|c|c|c|c|}
\hline & Microfinance =1 & Microfinance $=0$ & t-stat \\
\hline Male & $37.9 \%$ & $49.5 \%$ & -1.40 \\
\hline Age & 35.1 & 32.1 & 1.61 \\
\hline Education & 8.14 & 7.95 & 0.35 \\
\hline Concrete & $63.1 \%$ & $54.2 \%$ & 1.05 \\
\hline Kuywepe & $18.5 \%$ & $20.6 \%$ & 0.19 \\
\hline Electricity & $22.2 \%$ & $19.8 \%$ & 0.21 \\
\hline Solar & $14.3 \%$ & $6.7 \%$ & 0.54 \\
\hline Farmer & $66.7 \%$ & $56.7 \%$ & 1.51 \\
\hline Trader & $22.7 \%$ & $21.2 \%$ & 0.14 \\
\hline Teacher & $12.1 \%$ & $13.1 \%$ & -0.08 \\
\hline Student & $0.0 \%$ & $6.1 \%$ & -0.40 \\
\hline Boda & $1.5 \%$ & $3.0 \%$ & -0.10 \\
\hline Skill & $12.1 \%$ & $11.1 \%$ & 0.08 \\
\hline
\end{tabular}

As one can see, there are not important differences in the samples. Recipients of microfinance loans are more likely to be women who are slightly older and better educated. These differences, though, are not statistically significant. The wealth levels, as measured by the quality of their housing, shows no significant pattern or magnitude of difference. Recipients are more likely to be farmers and less likely to be students, but, again, these differences are statistically insignificant. Thus, based on observables, the microfinance recipients are not distinct from the population as a whole.

Additionally, the sign and statistical significance of Microfinance remains intact as background, occupation, wealth, and income is controlled for. Thus, even for individuals with similar characteristics, those who have received the financial support free ride less. Therefore, selection bias does not seem to have much of an impact on the results.

Nevertheless, as a robustness check on the main results, a Propensity Score Matching method (hereafter PSM) is employed to directly, econometrically address the potential sample selection bias. In PSM a first-stage regression is done estimating the likelihood an observation is in the treatment sample, 
here being a recipient of a microfinance loan. For each observation in the treatment, the observation in the non-treatment sample is identified that has the closest fitted value of the dependent variable. The set of the closest matches becomes the control sample. The means of the treated and control samples can be compared.

Table A3 in the appendix provides the first-stage binary logit estimation results. The background controls and occupations are used. These estimated coefficients are used to calculate a fitted value of Contribution for each observation. It is possible that multiple treated observations best match with the same control. Thus, while the treatment sample has 64 observations, the control sample has 46 . Table 8 presents the results from the PSM method.

TABLE 8: Propensity Score Matching

\begin{tabular}{|c|c|c|c|c|}
\hline & Treatment & Control $\{\Delta\}$ & OLS & WLS \\
\hline Microfinance & 3.328 & $3.196 \quad\{+0.13\}$ & $\begin{array}{l}0.292 * * \\
(0.134)\end{array}$ & $\begin{array}{l}0.255 * \\
(0.139)\end{array}$ \\
\hline Norm & 2.833 & $3.224 \quad\{-0.39\}$ & $\begin{array}{l}0.189 * * \\
(0.074)\end{array}$ & $\begin{array}{l}0.181 * * \\
(0.076)\end{array}$ \\
\hline Dictator & 3.429 & $3.565 \quad\{-0.14\}$ & $\begin{array}{l}0.577 * * \\
(0.073)\end{array}$ & $\begin{array}{l}0.572 * * * \\
(0.078)\end{array}$ \\
\hline
\end{tabular}

The control sample (of non-recipients) has a slightly higher average contribution than the overall sample of individuals who have not received microfinance loans (3.010). An important increase in public good contribution still arises due to the microfinance treatment. Also, again, expectations of others' contributions are lower. The expectations of the control group are substantially larger than the overall sample of non-recipients (3.094). This escalates the difference between the control and treated samples. Similarly, the control group exhibits higher levels of Dictator Game giving (3.414). This indicates that selection effects are prevalent in these two dimensions.

The final two columns provide estimation results considering only the data set consisting of the control and treatment groups. The first presents results from an OLS estimation. Once again, having 
received a microfinance loan increases the size of the public goods contribution. The second column presents results from a weighted least squares estimation. As is rather common in PSM analysis, the observations in the control sample are weighted by the number of observations in the treatment sample that map to it. Once again, the sign and statistical significance of Microfinance persists (along with that of Norms and Dictator).

Thus, addressing the potential selection bias of receiving a microfinance loan (using PSM), the main findings persist. Microfinance loan recipients are more willing to contribute to a public good. This affect cannot be assigned to changes in social norms, income and wealth, or selection bias. Thus, it is reasonable to argue that microfinance impacts individuals' social preferences encouraging pro-social behaviors. ${ }^{19}$

\section{Concluding Discussion}

We ask whether microfinance efforts in the poorest, undeveloped parts of the world have an unintended effect onto pro-social behaviors. To answer this question, the Public Goods Game experiment is conducted with adults in rural, southern Uganda where some subjects have previously received microfinance support while others in the community have not. We first identify a relatively large, positive impact on public good contributions. Those who have received microfinance loans free ride less. We then explore multiple alternative hypotheses regarding the channel through which this operates. While social norms and income/wealth matter, the impact of microfinance exposure works independently. Thus, we argue that being a recipient of a microfinance loan facilitates pro-social preferences. The effect cannot be attributed to selection effects either.

It is important to appreciate the impact of microfinance interventions by NGOs on the communities they reach. The "social capital" of a society can have a large and sustained economic

\footnotetext{
${ }^{19}$ PSM is one, popular method to addressing potential sample selection bias. An alternative is to recognize the endogeneity of the lending and use an instrument in a two-stage least squares estimation. The variable Farm: $C_{0}$ $O p$ can be used as a variable. It is highly correlated with Microfinance, $r=0.3$ with $p=0.0001$, and uncorrelated with Contribution, $r=0.03$ with $p=0.68$. Also, intuitively, it is an appropriate instrument. Microfinance typically looks for peer effects to resolve moral hazard and adverse selection problems. Cooperative farming provides that. Thus, selection is based to a degree on the prevalence of cooperative farming. Using as it as an instrument, Microfinance has a positive and statistically significant coefficient in the second-stage analysis. Thus, the main finding is robust.
} 
impact (Knack and Keefer, 1997). While microfinance loans provide economic opportunities, which, for example, can reinforce positive interactions with others facilitating pro-social preferences, one could be concerned of deteriorated social interconnectedness. For example, Krishan and Sciubba (2009) highlight the importance of social networks amongst Nigerian farmers. The results presented suggest a previously unidentified benefit of microfinance interventions.

Willingness to contribute to a public good is an especially important pro-social behavior to analyze. In the community studied, publicly-provided services are rare. Thus, public goods must be provided privately or through philanthropic-minded outsiders. The finding that microfinance interventions have a positive effect can be expected to be a welcome, unintended benefit to the society being served.

The hypothesis we proposed and tested is that changes in economic institutions, or more appropriately, exposure to new institutions, affects the preferences of individuals. This broad question is not new. Bowles (1998) reviews at length research evaluating this possibility. He identifies five paths down which markets and other economic institutions can affect preferences. They are: (1) framing and situational construal, (2) intrinsic and extrinsic motivation, (3) effects on the evolution of norms, (4) task performance effects, and (5) effects on the process of cultural transmission. One can view the results presented here as an assessment of the effects of the introduction of new financial market opportunities on the extrinsic motivation of individuals, (2). Subjects are more willing to provide monetary contributions to others when they themselves have received external, financial support. ${ }^{20}$

The primary unresolved issue, then, is to identify how this effect on pro-social behavior is created. For example, group lending models are designed to use social interactions to facilitate repayment. Would microfinance loans without peer effects produce the same spillover? Alternatively, it could be the increased contact with markets, rather than focusing on self-sufficiency through subsistence agriculture, that promotes other-regarding behaviors. Identifying differences in the effect from alternative interventions would be useful in guiding economic development efforts.

Also, the work done here focuses on free riding behavior and the willingness to contribute to a public good. This is one particular (albeit important) pro-social behavior. While previous work has identified correlations between it and other behaviors, e.g. cooperation in Prisoner's Dilemma games

\footnotetext{
${ }^{2020}$ By engaging in a formal experiment where the decision problem is presented consistently across subjects, (1) is excluded. The econometric analysis rules out (3) as a driving explanation. We cannot rule out, though, the potential for microfinance to allow individuals to engage in new tasks that alter preferences, (4). Finally, given the relatively short time frame considered, cultural transmission across generations cannot be evaluated, (5).
} 
(DeAngelo and McCannon, 2016), future work may want to extend the analysis of positive behavioral effects to other social preferences.

Experimental economics is, of course, always exposed to the criticism that behavior in the laboratory does not coincide with real-world behavior (Levitt and List, 2007). Even a field study, where the laboratory experiment is taken to the subjects, designers must still create an artificial decision problem. Relatedly, as with any survey, inaccurate reporting of lending activities opens up the possibility of measurement error (Karlan and Zinman, 2008). To provide corroborating evidence, empirical data of microloan recipients' contributions to public goods in a more natural setting is called for.

An important limitation of the work is that, while it is hypothesized that the effect is directly on shaping social preferences, the utility functions of the subjects are not observable. The empirical work can only rule out alternatives: social norms, income effects, and selection bias. Nevertheless, experimental games minimize the number of confounding variables so that preference elicitation is to be expected (Andreoni, 1995). Finally, while we econometrically address the potential for sample selection effects driving the results, an ideal study would have assessed behavior prior to being treated with the microfinance and/or would have utilized a randomized selection process. Future investigations could intervene prior to the disbursement of the microloans to ensure the robustness of the findings presented here.

\section{References}

Alesina, Alberto, and Nicola Fuchs-Schündeln (2007), Goodbye Lenin (Or Not?): The Effect of Communism on People, American Economic Review 97(4): 1507-1528.

Angelucci, Manuela, Dean Karlan, and Jonathan Zinman (2015), Microcredit Impacts: Evidence from a Randomized Microcredit Program Placement Experiment by Compartamos Banco, American Economic Journal: Applied Economics 7(1): 151-82.

Anderson, Lisa R., and Jennifer M. Mellor (2009), Religion and Cooperation in a Public Goods Experiment, Economics Letters 105(1): 58-60. 
Andreoni, James (1990), Impure Altruism and Donations to Public Goods: A Theory of Warm Glow Giving, Economic Journal 100(401): 464-477.

Andreoni, James (1995), Cooperation in Public Goods Experiments: Kindness or Confusion?, American Economic Review 85(4): 891-904.

Ariely, Dan, Ximena Garcia-Rada, Lars Hornuf, and Heather Mann (2014), The (True) Legacy of Two Really Existing Economic Systems, University of Munich Discussion Paper No. 2014-26.

Attanasio, Orazio, Britta Augsburg, Ralph De Haas, Emla Fitzsimons, and Heike Harmgart (2015), The Impacts of Microfinance: Evidence from Joint-Liability Lending in Mongolia, American Economic Journal: Applied Economics 7(1): 90-122.

Augsburg, Britta, Ralph De Haas, Heike Harmgart, and Costas Meghir (2015), The Impacts of Microcredit: Evidence from Bosnia and Herzegovina, American Economic Journal: Applied Economics 7(1): 183-203.

Banerjee, Abhijit, and Esther Duflo (2011), Poor Economics: A Radical Rethinking of the Way to Fight Global Poverty, New York: Public Affairs.

Banerjee, Abhijit, Esther Duflo, Rachel Glennerster, and Cynthia Kinnan (2015), The Miracle of Microfinance? Evidence from a Randomized Evaluation, American Economic Journal: Applied Economics $7(1): 22-53$.

Banerjee, Abhijit, Esther Duflo, and Richard Hornbeck (2014), Bundling Health Insurance and Microfinance in India: There Cannot be Adverse Selection If There Is No Demand, American Economic Review 104(5): 291-297.

Banerjee, Abhijit, Dean Karlan, and Jonathan Zinman (2015), Six Randomized Evaluations of Microcredit: Introduction and Further Steps, American Economic Journal: Applied Economics 7(1): 1-21.

Barr, Abigail (2003), Trust and Expected Trustworthiness: Experimental Evidence from Zimbabwean Villages, Economic Journal 113(489): 614-630. 
Becchetti, Leonardo, Pierluigi Conzo, and Alessandro Romeo (2014), Violence, Trust, and Trustworthiness: Evidence from a Nairobi Slum, Oxford Economic Papers 66(1): 283-305.

Beekman, Gonne, Erwin Bulte, and Eleonora Nillesen (2014), Corruption, Investments, and Contributions to Public Goods: Experimental Evidence from Rural Liberia, Journal of Public Economics 115(1): 37-47.

Bauer, Michal, Julie Chytilová, and Jonathan Morduch (2012), Behavioral Foundations of Microcredit: Experimental and Survey Evidence from Rural India, American Economic Review 102(2): 1118-1139.

Bicchieri, Cristina (2006), The Grammar of Society: The Nature of Dynamics of Social Norms, Cambridge University Press.

Bicchieri, Cristina, and Alex Chavez (2010), Behaving as Expected: Public Information and Fairness Norms, Journal of Behavioral Decision Making 23(2): 161-178.

Bicchieri, Cristina, and Erte Xiao (2007), Do the Right Thing, But Only if Others Do, Journal of Behavioral Decision Making 22(2): 191-208.

Blattman, Christopher, Nathan Fiala, and Sebastian Martinez (2014), Generating Skilled Self-Employment in Developing Countries: Experimental Evidence from Uganda, Quarterly Journal of Economics 129(2): 697-752.

Bond, Philip, and Arvind Krishnamurthy (2004), Regulating Exclusion from Financial Markets, Review of Economic Studies 71(3): 681-707.

Bowles, Samuel (1998), Endogenous Preferences: The Cultural Consequences of Markets and Other Economic Institutions, Journal of Economic Literature 36(1): 75-111.

Bryan, Gharad, Dean Karlan, and Jonathan Zinman (2015), Referrals: Peer Screening and Enforcement in a Consumer Credit Field Experiment, American Economic Journal: Microeconomics 7(3): 174-204. 
Buckley, Edward, and Rachel Croson (2008), Income and Wealth Heterogeneity in Voluntary Provision of Linear Public Goods, Journal of Public Economics 90(4-5): 935-955.

Cassar, Alessandra, Luke Crowley, and Bruce Wydick (2007), The Effect of Social Capital on Group Loan Repayment: Evidence from Field Experiments, Economic Journal 117(517): F85-F106.

Cassar, Alessandra, Pauline Grosjean, Sam Whitt (2013), Legacies of Violence: Trust and Market Development, Journal of Economic Growth 18(3): 285-313.

Cassar, Alessandra, and Bruce Wydick (2010), Does Social Capital Matter? Evidence from a Five-Country Group Lending Experiment, Oxford Economics Papers 62(4): 715-739.

Carlton, Andy, Hannes Manndorff, Andrew Obara, Walter Reiter, and Elisabeth Rhyne (2001), Microfinance in Uganda, Austrian Ministry of Foreign Affairs.

Chaudhuri, Ananish (2011), Sustaining Cooperation in Laboratory Public Goods Experiments: A Selective Survey of the Literature, Experimental Economics 14(1): 47-83.

Chen, Gongmeng, Kenneth A. Kim, John R. Nofsinger, and Oliver M. Rui (2007), Trading Performance, Disposition Effects, Overconfidence, Representation Bias, and Experience of Emerging Market Investors, Journal of Behavioral Decision Making 20(4): 425-451.

Cinyabuguma, Matthias, Talbot Page, and Louis Putterman (2005), Cooperation under the Threat of Expulsion in a Public Goods Experiment, Journal of Public Economics 89(8): 1421-1435.

Crépon, Bruno, Florencia Devoto, Esther Duflo, and William Parienté (2015), Estimating the Impact of Microcredit on Those Who Take It Up: Evidence from a Randomized Experiment in Morocco, American Economic Journal: Applied Economics 7(1): 123-50.

Conning, Jonathan, and Christopher Udry (2005) Rural Financial Markets in Developing Countries, in Robert E. Evenson, and Prabhu Pingali (eds.), Handbook of Agricultural Economics, Volume 3, NorthHolland. 
Cox, James C. (2004), How to Identify Trust and Reciprocity, Games and Economic Behavior 46(2): 260281.

Cull, Robert, Asli Demirgüç-Kunt, and Jonathan Morduch (2007), Financial Performance and Outreach: A Global Analysis of Leading Microbanks, Economic Journal 117(517): F107-F133.

Cull, Robert, Asli Demirgüç-Kunt, and Jonathan Morduch (2009), Microfinance Meets the Market, Journal of Economic Perspectives 23(1): 167-192.

Cull, Robert, Asli Demirgüç-Kunt, and Jonathan Morduch (2011), Does Regulatory Supervision Curtail Microfinance Profitability and Outreach?, World Development 39(6): 949-965.

de Mel, Suresh, David McKenzie, and Christopher Woodruff (2008), Returns to Capital in Microenterprises: Evidence from a Field Experiment, Quarterly Journal of Economics 123(4): 1329-1372.

DeAngelo, Gregory, and Bryan C. McCannon (2016), Do Psychological Traits Explain Differences in Free Riding Behavior?, Working Paper.

El-Gamal, Mahmoud, Mohamed El-Komi, Dean Karlan, and Adam Osman (2014), Bank-Insured RoSCA for Microfinance: Experimental Evidence in Poor Egyptian Villages, Journal of Economic Behavior and Organization 113: S56-S76.

Fafchamps, Marcel, and Ruth Vargas Hill (2015), Redistribution and Group Participation: Comparative Experimental Evidence of Africa and the UK, Working Paper.

Farber, Henry S. (2015), Why You Can't Find a Taxi in the Rain and Other Labor Supply Lessons from Cab Drivers, Quarterly Journal of Economics 130(4): 1975-2026.

Fehr, Ernst, and Urs Fischbacher (2002), Why Social Preferences Matter - The Impact of Non-Selfish Motives on Competition, Cooperation, and Incentives, Economic Journal 112(478): C1-C33. 
Fehr, Ernst, and Simon Gächter (2000), Cooperation and Punishment in Public Goods Experiments, American Economic Review 90(4): 980-994.

Feigenberg, Benjamin, Erica Field, and Rohini Pande (2013), The Economic Returns to Social Interaction: Experimental Evidence from Microfinance, Review of Economic Studies 80(4): 1459-1483.

Feigenberg, Benjamin, Erica Field, Rohini Pande, Natalia Rigol, and Shayak Sarkar (2014), Do Group Dynamics Influence Social Capital Gains Among Microfinance Clients? Evidence from a Randomized Experiment in Urban India, Journal of Policy Analysis and Management 33(4): 932-949.

Field, Erica, and Rohini Pande (2008), Repayment Frequency and Default in Microfinance: Evidence from India, Journal of the European Economic Association 6(2-3): 501-509.

Field, Erica, Rohini Pande, John Papp, and Natalia Rigol (2013), Does the Classical Microfinance Model Discourage Entrepreneurship Among the Poor? Experimental Evidence from India, American Economic Review 103(6): 2196-2226.

Fischer, Greg (2013), Contract Structure, Risk-Sharing, and Investment Choice, Econometrica 81(3): 883939.

Gächter, Simon, Daniele Nosenzo, and Martin Sefton (2013), Peer Effects in Pro-Social Behavior: Social Norms or Social Preferences?, Journal of the European Economic Association 11(3): 548-573.

Ghatak, Maitreesh (1999), Group Lending, Local Information and Peer Selection, Journal of Development Economics 60(1): 27-50.

Ghatak, Maitreesh (2000), Screening by the Company You Keep: Joint Liability Lending and the Peer Selection Effect, Economic Journal 110(465): 601-31.

Ghatak, Maitreesh, and Timothy W. Guinnane (1999), The Economics of Lending with Joint Liability: Theory and Practice, Journal of Development Economics 60(1): 195-228. 
Giné, Xavier, Pamela Jakiela, Dean Karlan, and Jonathan Murdoch (2010), Microfinance Games, American Economic Journal: Applied Economics 2(1): 60-90.

Gode, Dhananjay K., and Shyam Sunder (1993), Allocative Efficiency of Markets with Zero-Intelligence Traders: Markets as a Partial Substitute for Individual Rationality, Journal of Political Economy 101(1): 119-137.

Greaney, Brian, Joseph P. Kaboski, and Eva Van Leemput (2016), Can Self-Help Groups Really Be "SelfHelp"?, Review of Economic Studies, forthcoming.

Gwartney, James, Robert Lawson, and Joshua Hall (2015), Economic Freedom of the World: 2015 Annual Report, Fraser Institute.

Haigh, Michael S., and John A. List (2005), Do Professional Traders Exhibit Myopic Loss Aversion? An Experimental Study, Journal of Finance 60(1): 523-534.

Hamad, Rita, Lia C.H. Fernald, and Dean S. Karlan (2011), Health Education for Microcredit Clients in Peru: A Randomized Controlled Trial, BMC Public Health 11(1): 51-60.

Harrison, Glenn W., and John A. List (2004), Field Experiments, Journal of Economic Literature 42(4): 1009-1055.

Henrich, Joseph, Robert Boyd, Samuel Bowles, Colin Camerer, Ernst Fehr, Herbert Gintis, and Robert McElreath (2001), In Search of Homo Economicus: Behavioral Experiments in 15 Small-Scale Societies, American Economic Review 91(2): 73-78.

Henrich, Joseph, Robert Boyd, Samuel Bowles, Colin Camerer, Ernst Fehr, Herbert Gintis, and Robert McElreath (2004), Foundations of Human Sociality, Oxford University Press.

Isaac, R. Mark, and James M. Walker (1988), Group Size Effects in Public Goods Provision: The Voluntary Contribution Mechanism, Quarterly Journal of Economics 103(1): 179-199. 
Isaac, R. Mark, James M. Walker, and Arlington W. Williams (1994), Group Size and Voluntary Provision of Public Goods: Experimental Evidence Utilizing Large Groups, Journal of Public Economics 54(1): 1-36.

Jack, B. Kelsey, and Maria P. Recalde (2015), Leadership and Voluntary Provision of Public Goods: Field Evidence from Bolivia, Journal of Public Economics 122(1): 80-93.

Jakiela, Pamela, and Owen Ozier (2016), Does Africa Need a Rotten Kid Theorem? Experimental Evidence from Village Economies, Review of Economic Studies 81(3): 231-268.

Kaboski, Joseph P., and Robert M. Townsend (2011), A Structural Evaluation of a Large-Scale QuasiExperimental Microfinance Initiative, Econometrica 79(5): 1357-1406.

Kaboski, Joseph P., and Robert M. Townsend (2012), The Impact of Credit on Village Economies, American Economic Journal: Applied Economics 4(2): 98-133.

Kahneman, Daniel, Jack L. Knetsch, and Richard Thaler (1986), Fairness and the Assumptions of Economics, Journal of Business 59(4): S285-S300.

Karlan, Dean (2005), Using Experimental Economics to Measure Social Capital and Predict Financial Decisions, American Economic Review 95(5): 1618-1699.

Karlan, Dean S. (2007), Social Connections and Group Banking, Economic Journal 117(517): F52-F84.

Karlan, Dean, Melanie Morten, and Jonathan Zinman (2016), A Personal Touch: Text Messaging for Loan Repayment, Behavioral Science and Policy, forthcoming.

Karlan, Dean, Robert Osei, Isaac Osei-Akoto, and Christopher Udry (2014), Agriculture Decisions after Relaxing Credit and Risk Constraints, Quarterly Journal of Economics 129(2): 597-652.

Karlan, Dean, and Martin Valdivia (2011), Teaching Entrepreneurship: Impact of Business Training on Microfinance Clients and Institutions, Review of Economics and Statistics 93(2): 510-527. 
Karlan, Dean, and Jonathan Zinman (2008), Lying about Borrowing, Journal of the European Economic Association 6(2-3): 510.521.

Karlan, Dean, and Jonathan Zinman (2010), Expanding Credit Access: Using Randomized Supply Decisions to Estimate the Impacts, Review of Financial Studies 23(1): 433-464.

Karlan, Dean, and Jonathan Zinman (2011), Microcredit in Theory and Practice: Using Randomized Credit Scoring for Impact Evaluation, Science 332: 1278-1284.

Knack, Stephen, and Philip Keefer (1997), Does Social Capital Have an Economic Payoff? A Cross-Country Investigation, Economic Journal 112(4): 1251-1288.

Kremer, Michael, and Edward Miguel (2007), The Illusion of Sustainability, Quarterly Journal of Economics 122(3): 1007-1065.

Krishnan, Pramila, and Emanuela Sciubba (2009), Links and Architecture in Village Network, Economic Journal 119(537): 917-949.

Krupka, Erin L., and Roberto A. Weber (2013), Identifying Social Norms Using Coordination Games: Why Does Dictator Game Sharing Vary?, Journal of the European Economic Association 11(3): 495-524.

Ledyard, John O. (1995), Public Goods: A Survey of Experimental Research, in John Kagel and Alvin Roth (eds.), Handbook of Experimental Economics, Princeton University Press, 111-193.

Lehrer, Kim, and Catherine Porter (2015), Charitable Dictators? Determinants of Giving to NGOs in Uganda, Working Paper.

Levitt, Steven D., and John A. List (2007), What Do Laboratory Experiments Measuring Social Preferences Reveal About the Real World?, Journal of Economic Perspectives 21(2): 153-174. 
Levitt, Steven D., John A. List, and Steven H. Reilly (2010), What Happens in the Field Stays in the Field: Exploring Whether Professionals Play Minmax in Laboratory Experiments, Econometrica 78(4): 14131434.

List, John A. (2001), Do Explicit Warnings Eliminate the Hypothetical Bias in Elicitation Procedures? Evidence from Field Auctions for Sportscards, American Economic Review 91(5): 1498-1507.

List, John A. (2003), Does Market Experience Eliminate Market Anomalies?, Quarterly Journal of Economics 118(1): 41-71.

List, John A. (2007), On the Interpretation of Giving in Dictator Games, Journal of Political Economy 115(3): 482-493.

List, John A., and Daniel L. Millimet (2008), The Market: Catalyst for Rationality and Filter of Irrationality, BE Journal of Economic Analysis and Policy: Frontiers 8(1): Article 7.

McCannon, Bryan C. (2014), Trust, Reciprocity, and a Preference for Economic Freedom: Experimental Evidence, Journal of Institutional Economics 10(3): 451-470.

McCannon, Bryan C. (2014), Finance Education and Social Preferences: Experimental Evidence, Journal of Behavioral and Experimental Finance 1(4): 42-57.

McIntosh, Craig and Bruce Wydick (2005), Competition and Microfinance, Journal of Development Economics 78(2): 271-298.

McIntosh, Craig, Alain de Janvry, and Elisabeth Sadoulet (2005), How Rising Competition Among Microfinance Institutions Affects Incumbent Lenders, Economic Journal 115(506): 987-1004.

Morduch, Jonathan (1999a), The Microfinance Promise, Journal of Economic Literature 37(4): 15691614. 
Morduch, Jonathan (1999b), The Role of Subsidies in Microfinance: Evidence from the Grameen Bank, Journal of Development Economics 60: 229-248.

Mutyaba, Gertrude (2014), Rakai: Where Uganda's HIV Fight Began, Sunday Monitor (February 10).

Nalugoda, Fred, Maria J. Wawerb, Joseph K. Konde-Lulec, Rekha Menond, Ronald H. Graye, David Serwaddaa, Nelson K. Sewankambof, and Chuanjin Lie (1997), HIV Infection in Rural Households, Rakai District, Uganda, Health Transition Review 7(1): 127-140.

Nowell, Clifford, and Sarah Tinkler (1994), The Influence of Gender on the Provision of a Public Good, Journal of Economic Behavior and Organization 25(1): 25-36.

Odean, Terrance (1998a), Are Investors Reluctant to Realize Their Losses?, Journal of Finance 53(5): 1775-1798.

Odean, Terrance (1998b), Volume, Volatility, Price, and Profit When All Traders are Above Average, Journal of Finance 53(6): 1887-1934.

Odean, Terrance (1999), Do Investors Trade Too Much?, American Economic Review 89(5): 1279-1298.

Oprea, Ryan, Gary Charness, Daniel Friedman (2014), Continuous Time and Communication in PublicGoods Experiment, Journal of Economic Behavior and Organization 108: 212-223.

Palacios-Huerta, Ignacio, and Oscar Volij (2008), Experientia Docet: Professionals Play Minmax in Laboratory Experiments, Econometrica 76(1): 71-115.

Pitt, Mark M., and Shahidur Khandker (1998), The Impact of Group-Based Credit Programs on Poor Households in Bangladesh: Does the Gender of Participants Matter?, Journal of Political Economy 106(5): 958-996.

Pope, Devin G., and Maurice E. Schweitzer (2011), Is Tiger Woods Loss Averse? Persistent Bias in the Face of Experience, Competition, and High Stakes, American Economic Review 101(1): 129-157. 
Rai, Ashok S., and Tomas Sjöström (2004), Is Grameen Lending Efficient? Repayment Incentive and Insurance in Village Economies, Review of Economic Studies 71(1): 217-234.

Reuben, Ernesto, and Arno Riedl (2008), Enforcement of Contribution Norms in Public Goods Games with Heterogeneous Populations, Games and Economic Behavior 77(1): 122-137.

Roodman, David, and Jonathan Morduch (2014), The Impact of Microcredit on the Poor in Bangladesh: Revisiting the Evidence, Journal of Development Studies 50(4): 583-604.

Sachs, Jeffrey (2008), The Merits of Microfinance as a Viable Solution for Poverty Alleviation: An Interview with Jeffrey Sachs, Whitehead Journal of Diplomacy and International Relations 9(2): 11-17.

Sera, Danila, Pieter Serneels, and Abigail Barr (2011), Intrinsic Motivation and the Non-Profit Health Sector: Evidence from Ethiopia, Personality and Individual Differences 51(3): 309-314.

Sewankambo, Nelson K., Ronald H. Gray, Saifuddin Ahmad, David Serwadda, Fred Wabwire-Mangen, Fred Nalugoda, Noah Kiwanuka, Tom Lutalo, Godfrey Kigozi, Chuanjun Li, Mary P. Meehan, Heena Brahmbatt, Maria J. Wawer (2000), Mortality Associated with HIV Infection in Rural Rakai District, Uganda, AIDS 14(15), 2391-2400.

Stiglitz, Joseph E. (1990), Peer Monitoring and Credit Markets, World Bank Economic Review 4(3): 351366.

Tarozzi, Alessandro, Jaikishan Desai, and Kristin Johnson (2015), The Impacts of Microcredit: Evidence from Ethiopia, American Economic Journal: Applied Economics 7(1): 54-89.

Tedeschi, Gwendolyn Alexander (2006), Here Today, Gone Tomorrow: Can Dynamic Incentives Make Microfinance More Flexible?, Journal of Development Economics 80(1): 84-105.

Whitt, Sam, and Rick K. Wilson (2007), Public Goods in the Field: Katrina Evacuees in Houston, Southern Economic Journal 74(2): 377-387. 
Xiao, Erte, and Daniel Houser (2011), Punish in Public, Journal of Public Economics 95(7): 1006-1017.

Yunus, Muhammad (1999), Banker to the Poor: Micro-lending and the Battle against World Poverty, New York: Worth Publishers. 


\section{Appendix}

\section{Below is the English language script used in the experimental sessions.}

Welcome. We greatly appreciate your willingness to participate. The decisions you make in our game will help us with our research.

There are a few things you should know about the game today. First, you are going to be making decisions that affect how much money you will receive and how much money other people get. Similarly, how much money you receive will also depend on the choices made by others. We want to assure you that the choices you make will remain anonymous and confidential. At no time will the other participants know the decisions you made. We will not reveal any information about your choices to others. Second, we want to emphasize that participation in the research is voluntary. You may quit the game at any time and are free to leave. Third, the paper you have received provides contact information of Dr. Gary Ostrower. If at any time you feel as if you have not been treated fairly and with respect by us, you are encouraged to contact him. The game is designed so that you have the opportunity to gain money. At no time can you lose money and at no time should you be put at any risk.

If you consent to participating in our research, please sign the paper form.

Thank you.

We are going to be playing a game. On the table in front of you are five coins and a sealed bucket. You are going to be a part of a group of four individuals. Each of you has five coins. The decision you need to make is how many of your five coins you would like to put inside the bucket. The coins you do not put in the bucket are yours to keep. For every coin you put in the bucket we will add another one to the bucket.

Three others will soon also make the same decision of how many coins to put in the bucket. They will not know how many you contributed and you do not know how many they contributed.

After the four in your group make this choice, the coins in the bucket will be divided equally between the four of you. The amount of money you make in this research will be the number of coins you keep and your share of the bucket.

Let us provide an example. Suppose each individual keeps three coins and puts two coins in the bucket. This means that there are sixteen coins in the bucket. The four of you have put a total of eight coins in and we have added another eight coins. The sixteen coins in the bucket are split evenly so that each of you receives four coins. As a result, you will gain a total of seven coins - the three you kept and the four you received from the bucket.

Alternatively, suppose two individuals put all five coins in the bucket and two individuals put zero coins in the bucket. This means there are twenty coins in the bucket - the ten contributed by the first two people and the ten contributed by us. The coins in the bucket are evenly shared between the four of you so that each receives five coins from the bucket. The two individuals who did not keep any coins receive a total of five coins in the research and the two who kept all five coins receive a total of ten coins - the five they kept plus the five received from the bucket.

Those are two examples. You are free to make any decision you want.

[Take a few moments to answer questions, re-explain the game, and administer proficiency questions until you are confident that the subject comprehends the game.]

[Have them make their decision by physically placing coins in the bucket.]

Great! Thank you again!

[Send the subject to the survey room] 
The following is a copy of the table completed in the surveying.

\begin{tabular}{|l|l|}
\hline ID & \\
\hline [Gender] & \\
\hline Age & \\
\hline Married? (Never, currently, or in the past) & \\
\hline If "in the past", divorced or widowed? & \\
\hline \# of children & \\
\hline Occupation & \\
\hline If a farmer, do you participate in a co-op? & \\
\hline If a farmer, do you hire laborers to help? & \\
\hline$\quad$ If yes, how many? & \\
\hline If a farmer, do you grow crops or raise livestock? & \\
\hline If a crop farmer, which crops? & \\
\hline If a livestock farmer, which livestock? & \\
\hline How many? & \\
\hline If a trader/business owner, do hire workers? & \\
\hline If yes, how many? & \\
\hline How many years of school have you completed? & \\
\hline [Did the subject need the Lugandan translation?] & \\
\hline Have you or someone in your family received a microloan? & \\
\hline If yes, from whom? & \\
\hline If yes, you or your family member? & \\
\hline Have you or someone in your family received a bank loan? & \\
\hline If yes, you or your family member? & \\
\hline Have you ever received or contributed to a lending cooperative? & \\
\hline If yes, what form did it/they take? & \\
\hline Does your house have a concrete floor? & \\
\hline Is your house made of brick or is it mud hut (kuywepe)? & \\
\hline Does your house have electricity or solar? & \\
\hline Did you grow up as an orphan, without your biological parents? & \\
\hline
\end{tabular}


As discussed in Section 2, a number of small microfinance operations are functioning in the Rakai district. Table A1 breaks down the outcomes of the experiment by source of microfinance loan.

TABLE A1: Funding by Non-Profit Organizations

\begin{tabular}{|c|c|c|c|c|}
\hline \multirow[t]{2}{*}{ Organization } & \multirow{2}{*}{$\begin{array}{l}\% \text { of the Microfinance } \\
\text { Recipients }\end{array}$} & \multicolumn{3}{|c|}{ Subsample Means: } \\
\hline & & Contribution & Norm & Dictator \\
\hline Mikwano & $16.7 \%$ & 3.36 & 2.64 & 2.82 \\
\hline SACCO & $40.9 \%$ & 3.04 & 2.89 & 3.04 \\
\hline BRAC & $33.3 \%$ & 3.50 & 2.91 & 3.73 \\
\hline Others & $15.2 \%$ & 3.10 & 2.70 & 3.20 \\
\hline \multicolumn{2}{|c|}{ Overall - Microfinance } & 3.33 & 2.82 & 3.43 \\
\hline \multicolumn{2}{|c|}{ Overall - No Microfinance } & 3.01 & 3.09 & 3.41 \\
\hline
\end{tabular}

The observation for all microfinance lending is consistent across sources. The average amount contributed is greater for each organization than the sample of those never receiving a microloan. Similarly, expectations of behavior are consistently low. Variation in Dictator Game giving is prevalent, though. The "Other" category is predominantly FINCA, but one subject indicated a private moneylender was used, while a few others did not provide the source. This category merges these miscellaneous sources.

Additionally, a detailed breakdown of the self-reported farming activities of the subjects is collected. Table A2 presents further information. 


\begin{tabular}{llll}
\hline & & & \\
\% who grow maize & $86.0 \%$ & \% who have pigs & $81.5 \%$ \\
\% who grow beans & $83.9 \%$ & \% who have chickens & $51.9 \%$ \\
\% who grown g-nuts & $28.0 \%$ & \% who have goats & $34.6 \%$ \\
\% who grow coffee & $12.9 \%$ & \% who have cows & $21.0 \%$ \\
\% who grow cassava & $8.6 \%$ & & \\
\% who grow tomatoes & $6.5 \%$ & & \\
\% who grow bananas & $5.4 \%$ & & \\
\% other vegetables & $5.4 \%$ & & \\
\% other fruit & $3.2 \%$ & &
\end{tabular}

Casava growers include potato/sweet potato growers. Other vegetables include cabbage, carrots, green peppers, and soy. Other fruits include passion fruit and mango.

Of those who grow crops, almost all grow beans and maize. In fact, $41 \%$ of the sample of farmers grow one or both of these and no other food items. A sizeable proportion also harvest ground nuts. These are staples of Ugandan meals. Cassava, tomatoes, and bananas are also prevalent. Only coffee (and potentially bananas and other fruit) is a cash crop that is not directly consumed by the individual's family.

Regarding those who raise livestock, pigs are the most prevalent. Many also own chickens. Pigs produce multiple piglets per year and chickens provide eggs. Both of which can provide an income. Goats and cows are owned by only a minority of farmers.

As discussed in the text, Propensity Score Matching is used to identify an appropriate control group that best matches the individuals who received a microfinance loan. Table A1 presents the results from the first-stage, logit estimation. The background controls and occupations are used. 
TABLE A3: Propensity Score Matching: First-Stage Results

(Binary Logit, dependent variable $=$ Microfinance)

I

\begin{tabular}{|c|c|c|c|c|}
\hline Male & -0.710 & $(0.370)$ & $-0.804 * *$ & $(0.400)$ \\
\hline Age & 0.036 & $(0.018)$ & 0.027 & (0.019) \\
\hline Education & 0.126 & (0.069) & 0.091 & $(0.078)$ \\
\hline Day1 & 0.020 & $(0.357)$ & 0.022 & $(0.382)$ \\
\hline Trader & 0.643 & $(0.426)$ & 0.502 & $(0.440)$ \\
\hline Teacher & -0.294 & $(0.565)$ & -0.434 & $(0.640)$ \\
\hline Boda & 0.430 & (1.333) & 0.306 & (1.334) \\
\hline Skill & 1.475 & $(0.524)$ & $1.461 * * *$ & (0.533) \\
\hline Concrete & & & 0.104 & $(0.404)$ \\
\hline Kuywepe & & & -0.036 & $(0.474)$ \\
\hline Electricity & & & 0.300 & (0.489) \\
\hline Solar & & & 0.958 & $(0.666)$ \\
\hline constant & $-2.648 * *$ & $(1.056)$ & $-2.154 *$ & (1.113) \\
\hline McFadden $\mathrm{R}^{2}$ & 0.072 & & 0.080 & \\
\hline AIC & 216.1 & & 210.5 & \\
\hline$\%$ correct & $65.4 \%$ & & $66.9 \%$ & \\
\hline $\mathrm{N}$ & 159 & & 148 & \\
\hline
\end{tabular}

II

\footnotetext{
QML standard errors presented in parentheses.
}

The constructed control sample can be compared to the treated sample. Both the specification with background and occupation controls (Column I of Table A3), along with the addition of wealth controls (Column II of Table A3) are compared. The number of observations and, consequently, the size of the treatment group differ due to missing observations $(\mathrm{N}=64$ for Treatment 1 and $\mathrm{N}=62$ for Treatment 2). Similarly, the number of observations in the control samples is affected by the fact that the matching method is not one-for-one, that is, two (or more) treated observations may be best matches with the same non-treated control observation ( $\mathrm{N}=46$ for Control 1 and $\mathrm{N}=35$ for Control 2). Table A4 presents the comparisons. 
TABLE A4: Comparing the Treated to Control Samples

\begin{tabular}{|c|c|c|c|c|c|c|}
\hline & Treatment 1 & Control 1 & Treatment 2 & Control 2 & OLS 2 & WLS 2 \\
\hline Male & $37.5 \%$ & $41.3 \%$ & $35.5 \%$ & $47.2 \%$ & & \\
\hline Age & 35.3 & 35.6 & 35.4 & 36.9 & & \\
\hline Education & 8.1 & 8.0 & 7.9 & 7.8 & & \\
\hline Farmer & $65.6 \%$ & $58.7 \%$ & $64.5 \%$ & $66.7 \%$ & & \\
\hline Trader & $23.4 \%$ & $19.6 \%$ & $24.2 \%$ & $11.1 \%$ & & \\
\hline Teacher & $12.5 \%$ & $15.2 \%$ & $11.3 \%$ & $8.3 \%$ & & \\
\hline Student & $0.0 \%$ & $2.2 \%$ & $0.0 \%$ & $0.0 \%$ & & \\
\hline Boda & $1.6 \%$ & $2.2 \%$ & $1.6 \%$ & $5.6 \%$ & & \\
\hline Skill & $18.8 \%$ & $13.0 \%$ & $19.4 \%$ & $11.1 \%$ & & \\
\hline Concrete & $63.5 \%$ & $57.8 \%$ & $62.9 \%$ & $52.8 \%$ & & \\
\hline Kuywepe & $19.0 \%$ & $28.3 \%$ & $19.4 \%$ & $27.8 \%$ & & \\
\hline Electricity & $22.6 \%$ & $20.5 \%$ & $22.6 \%$ & $17.1 \%$ & & \\
\hline Solar & $14.5 \%$ & $6.8 \%$ & $14.5 \%$ & $11.4 \%$ & & \\
\hline Contribution & & & 3.339 & 2.833 & & \\
\hline Norm & & & 2.828 & 2.944 & $\begin{array}{l}0.278 * * * \\
(0.079)\end{array}$ & $\begin{array}{r}0.253 * \\
(0.138)\end{array}$ \\
\hline Dictator & & & 3.426 & 3.583 & $\begin{array}{l}0.444 * * * \\
(0.081)\end{array}$ & $\begin{array}{c}0.451 * * * \\
(0.130)\end{array}$ \\
\hline Microfinance & & & & & $\begin{array}{l}0.615^{* * *} \\
(0.156)\end{array}$ & $\begin{array}{c}0.795^{* * *} \\
(0.205)\end{array}$ \\
\hline
\end{tabular}

From the first specification (the one used in the text), there are very little differences between the gender, age, or education of those in the treated and control samples. Likewise, the distribution of occupations is unaffected. Recipients consistently have better wealth levels (higher prevalence of brick houses with solid floors and electricity), but these differences are slight. None of the differences in these variables, from an (unbalanced) difference in means test, has statistical significance at even the $10 \%$ level.

The second column of Table A2 includes the wealth/housing variables in the matching algorithm. The differences in the treatment and control samples are more pronounced. The control 
sample is less female and has a lower prevalence of traders, teachers, and students as it is made up of more farmers. The gap between the contributions of the treated and control samples is even more pronounced. The giving of microfinance loan recipients is $18 \%$ greater than the control sample. The final two columns replicate the work of Table 8 presenting the results from both an OLS estimation and a WLS estimation with the number of treated observations matching with each control variable as the weights. In both specifications, the coefficient on Microfinance is positive and statistically significant. Thus, the results presented in the text are not sensitive to the dimensions in which the control sample is identified.

The following photos provide a depiction of the setting of the field experiment. Figure $A 1$ is a picture of a translator covering the consent form with a research subject. Figure $A 2$ is a photograph of the inside of the Mikwano Microfinance building. The entrance to the two rooms where the Public Goods Game was played can be seen. Figure A3 shows the inside of one of these rooms with the five 500 UGX coins and the bucket on a bench.

Figure A1: Consent Form

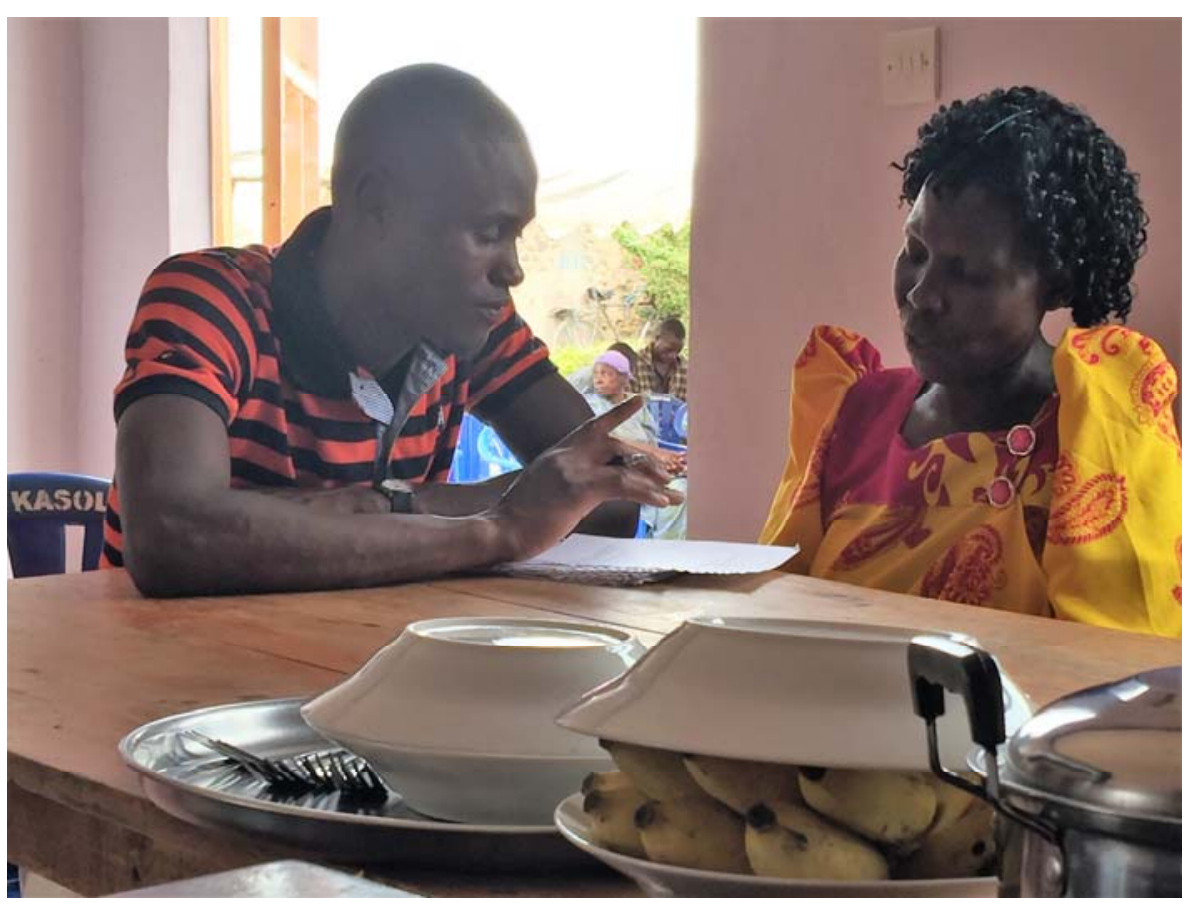


Figure A2: Mikwano Microfinance

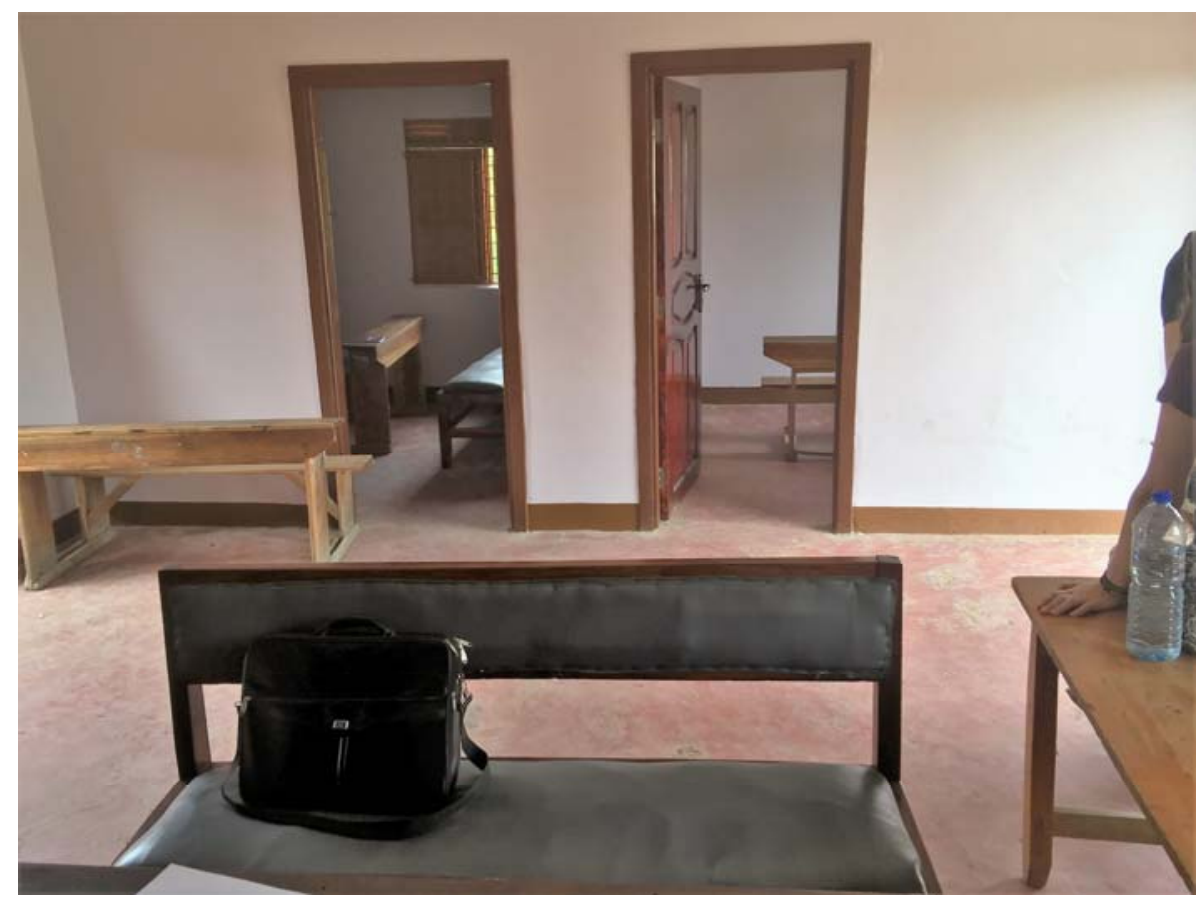

Figure A3: Public Goods Game

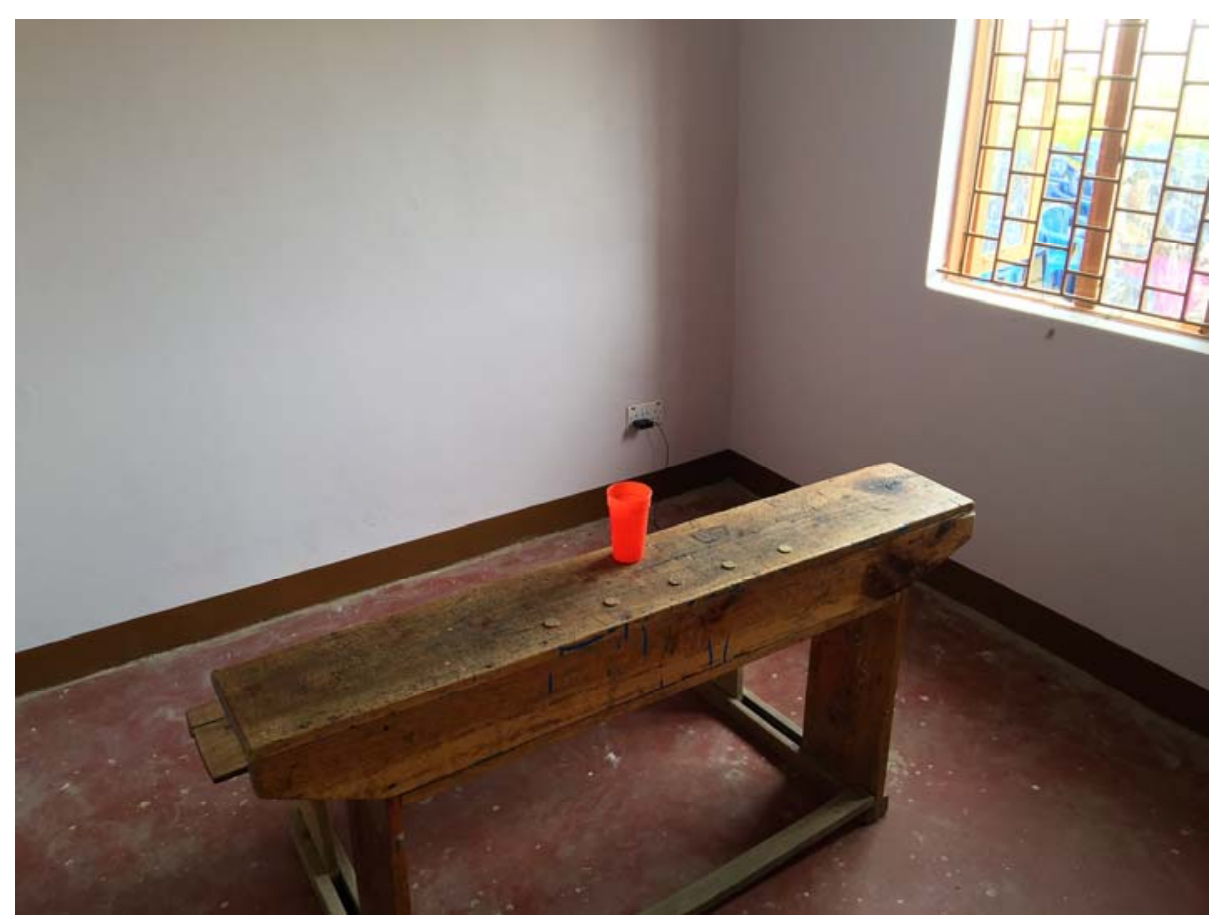




\section{Supplemental Appendix}

The main results in Tables 4 and 6 provide OLS estimates. OLS does not take into consideration the discrete nature of the data. The dependent variable Contribution only takes values of 1, 2, 3, 4, or 5 . Thus, both a count data model and an ordered probit are estimated and presented below.

TABLE S1: Alternative Models

\begin{tabular}{|c|c|c|c|c|}
\hline \multirow[b]{2}{*}{ Microfinance } & \multicolumn{2}{|c|}{ Count Data (Poisson) } & \multicolumn{2}{|c|}{ Ordered Probit } \\
\hline & $0.113 * * *$ & $(0.037)$ & $0.653 * * *$ & (0.193) \\
\hline Norm & $0.075 * * *$ & $(0.020)$ & $0.443 * * *$ & (0.115) \\
\hline Dictator & $0.160 * * *$ & $(0.023)$ & $0.799 * * *$ & (0.123) \\
\hline Concrete & -0.056 & $(0.042)$ & -0.282 & $(0.221)$ \\
\hline Kuywepe & 0.035 & $(0.042)$ & 0.250 & (0.222) \\
\hline Electricity & -0.076 & $(0.054)$ & -0.305 & $(0.272)$ \\
\hline Solar & -0.113 & $(0.093)$ & -0.560 & $(0.430)$ \\
\hline Farm: $\mathrm{Co}-\mathrm{Op}$ & -0.002 & $(0.049)$ & 0.088 & (0.257) \\
\hline Farm: Work & -0.050 & $(0.063)$ & -0.305 & $(0.321)$ \\
\hline Farm: \# Work & 0.002 & $(0.015)$ & 0.040 & $(0.068)$ \\
\hline Farm: Crops & 0.041 & $(0.057)$ & 0.110 & (0.288) \\
\hline Farm: Live & 0.044 & $(0.050)$ & 0.216 & (0.266) \\
\hline Farm: Cows & -0.016 & $(0.072)$ & -0.099 & (0.365) \\
\hline Farm: \# Chick & $-5.9 \times 10^{-5}$ & $(0.0002)$ & -0.001 & (0.001) \\
\hline Trader: Work & 0.018 & $(0.078)$ & 0.002 & (0.411) \\
\hline Trader: \# Work & 0.003 & $(0.012)$ & 0.014 & $(0.056)$ \\
\hline Male & -0.019 & $(0.039)$ & -0.014 & (0.217) \\
\hline Age & -0.0001 & $(0.002)$ & -0.002 & (0.009) \\
\hline Education & 0.009 & $(0.008)$ & 0.046 & (0.045) \\
\hline Day 1 & -0.008 & $(0.042)$ & -0.113 & $(0.221)$ \\
\hline Trader & 0.058 & $(0.061)$ & 0.288 & (0.350) \\
\hline Teacher & 0.122 & $(0.087)$ & 0.758 & (0.497) \\
\hline Student & $0.204 * *$ & $(0.094)$ & $0.870 *$ & (0.504) \\
\hline Boda & -0.038 & $(0.076)$ & -0.268 & (0.387) \\
\hline Skill & 0.020 & $(0.060)$ & 0.116 & (0.332) \\
\hline constant & $0.246 *$ & $(0.130)$ & & \\
\hline McFadden $\mathrm{R}^{2}$ & 0.093 & & --- & \\
\hline AIC & 513.9 & & 345.9 & \\
\hline$\%$ correct & --- & & $57.5 \%$ & \\
\hline $\mathrm{N}$ & 146 & & 146 & \\
\hline
\end{tabular}


The main result, that microfinance opportunities are associated with improved pro-social behavior continue to hold even when controlling for differing sample characteristics, altruism differences, social norms, income, and wealth. Thus, the results are robust to the econometric model estimated.

Additionally, Table 5 analyzes the prevalence of social norm compliance using logit models. Table S2 provides estimation results for binary probit models. Furthermore, the results for all control variables are presented.

TABLE S2: Social Norms

\begin{tabular}{|c|c|c|c|c|}
\hline & \multicolumn{2}{|c|}{$\begin{array}{l}\text { Exceed } \\
\text { (Binary Probit) }\end{array}$} & \multicolumn{2}{|c|}{$\begin{array}{l}\text { Match } \\
\text { (Binary Probit) }\end{array}$} \\
\hline Microfinance & $0.668 * * *$ & $(0.242)$ & -0.289 & (0.428) \\
\hline Dictator & $0.389 * * *$ & $(0.116)$ & -0.087 & (0.168) \\
\hline Male & 0.063 & $(0.236)$ & -0.103 & (0.253) \\
\hline Age & -0.010 & $(0.011)$ & 0.015 & (0.011) \\
\hline Education & -0.035 & (0.043) & $0.161 * * *$ & (0.047) \\
\hline Day 1 & $-0.408 *$ & $(0.245)$ & -0.043 & (0.254) \\
\hline Concrete & -0.122 & $(0.257)$ & 0.164 & $(0.272)$ \\
\hline Kuywepe & 0.411 & $(0.289)$ & -0.297 & (0.311) \\
\hline Electricity & -0.482 & $(0.343)$ & 0.045 & (0.331) \\
\hline Solar & -0.115 & $(0.374)$ & 0.194 & (0.434) \\
\hline Trader & $0.525 *$ & (0.278) & $-0.632 * *$ & (0.319) \\
\hline Teacher & $1.185 * * *$ & (0.435) & $-1.117^{* *}$ & (0.477) \\
\hline Student & -0.273 & $(0.767)$ & 1.155 & $(0.727)$ \\
\hline Boda & -0.537 & $(0.713)$ & 0.910 & (0.644) \\
\hline Skill & -0.075 & (0.365) & 0.199 & (0.357) \\
\hline constant & $-1.062 * *$ & $(0.769)$ & $-1.727 * *$ & (0.774) \\
\hline McFadden $\mathrm{R}^{2}$ & 0.176 & & 0.151 & \\
\hline $\mathrm{AIC}$ & 198.6 & & 188.5 & \\
\hline$\%$ correct & $70.7 \%$ & & $74.1 \%$ & \\
\hline $\mathrm{N}$ & 147 & & 147 & \\
\hline
\end{tabular}


The results from the probit estimations mirror the logit estimations presented in the text. Microfinance recipients are more likely to exceed their beliefs regarding the social norm.

As discussed in the text, the decision to make a microloan is endogenous. Therefore, an IV approach is appropriate. We argue that the choice by the non-profit organization is affected by the application of co-operative farming. Microfinance frequently uses group lending to facilitate repayment. Thus, the variable Farm: Co-Op is used as an instrument. At first glance, this seems appropriate. It is highly correlated with receiving a microfinance loan $(r=0.3$ with $p=0.0001)$ and uncorrelated with the public goods contribution $(r=0.03$ with $p=0.68)$. Table S3 presents the results from the second-stage regression. Both an estimation including and excluding wealth controls is presented.

TABLE S3: Two Stage Least Squares

(dependent variable $=$ Contribution; instrument $=$ Farm: Co-Op)

\begin{tabular}{|c|c|c|c|c|}
\hline & \multicolumn{2}{|l|}{1} & \multicolumn{2}{|l|}{ II } \\
\hline Microfinance & $0.546 * * *$ & $(0.066)$ & $0.537 * * *$ & $(0.170)$ \\
\hline Norm & $0.272 * * *$ & $(0.077)$ & $0.273 * * *$ & $(0.069)$ \\
\hline Dictator & $0.507 * * *$ & (0.006) & $0.496 * * *$ & $(0.008)$ \\
\hline Occupation & \multicolumn{2}{|l|}{ YES } & \multicolumn{2}{|l|}{ YES } \\
\hline Wealth & \multicolumn{2}{|l|}{ NO } & \multicolumn{2}{|l|}{ YES } \\
\hline $\operatorname{Adj~} R^{2}$ & \multicolumn{2}{|l|}{0.421} & \multicolumn{2}{|l|}{0.459} \\
\hline AIC & \multicolumn{2}{|l|}{1627.8} & \multicolumn{2}{|l|}{1459.9} \\
\hline Hausman & \multicolumn{2}{|l|}{0.09} & \multicolumn{2}{|l|}{0.11} \\
\hline Weak & \multicolumn{2}{|l|}{13.4} & \multicolumn{2}{|l|}{8.9} \\
\hline & \multicolumn{4}{|c|}{$\begin{array}{l}\qquad * * * 1 \%, * * 5 \%, * 10 \% \text { level of significance } \\
\text { Standard errors presented in parentheses are clustered by session. } \\
\text { An F-stat on the Weak Instrument Test < } 10 \text { may indicate a weak instrument. } \\
\text { Hausman test with a null hypothesis that the OLS estimates are consistent. } \\
\text { Wealth controls are Concrete, Kuywepe, Electricity, and Solar. }\end{array}$} \\
\hline
\end{tabular}

The importance of being a microloan recipient persists. The weak instrument test suggests the Farm: $\mathrm{Co}^{-}$ $O p$ is an acceptable instrument. The Hausman test, though, suggests that OLS is consistent. Regardless, the positive and highly statistically significant coefficient on Microfinance indicates that recipients engage in more pro-social behaviors. This effect does not seem to be explained by the endogeneity of the loan granting. 